The University of Maine

\title{
DigitalCommons@UMaine
}

Earth Science Faculty Scholarship

Earth Sciences

6-10-1995

\section{Landscape Evolution of the Dry Valleys, Transantarctic Mountains: Tectonic Implications}

David E. Sugden

George H. Denton

University of Maine - Main, gdenton@maine.edu

David R. Marchant

Follow this and additional works at: https://digitalcommons.library.umaine.edu/ers_facpub Part of the Earth Sciences Commons

\section{Repository Citation}

Sugden, David E.; Denton, George H.; and Marchant, David R., "Landscape Evolution of the Dry Valleys, Transantarctic Mountains: Tectonic Implications" (1995). Earth Science Faculty Scholarship. 55.

https://digitalcommons.library.umaine.edu/ers_facpub/55 


\title{
Landscape evolution of the Dry Valleys, Transantarctic Mountains: Tectonic implications
}

\author{
David E. Sugden \\ Department of Geography, University of Edinburgh, Edinburgh, Scotland
}

George H. Denton

Department of Geological Sciences and Institute for Quaternary Studies, University of Maine, Orono

David R. Marchant ${ }^{1}$

Department of Geography, University of Edinburgh, Edinburgh, Scotland

\begin{abstract}
There are different views about the amount and timing of surface uplift in the Transantarctic Mountains and the geophysical mechanisms involved. Our new interpretation of the landscape evolution and tectonic history of the Dry Valleys area of the Transantarctic Mountains is based on geomorphic mapping of an area of $10,000 \mathrm{~km}^{2}$. The landforms are dated mainly by their association with volcanic ashes and glaciomarine deposits and this permits a reconstruction of the stages and timing of landscape evolution. Following a lowering of base level about $55 \mathrm{~m} . y$. ago, there was a phase of rapid denudation associated with planation and escarpment retreat, probably under semiarid conditions. Eventually, downcutting by rivers, aided in places by glaciers, graded valleys to near present sea level. The main valleys were flooded by the sea in the Miocene during a phase of subsidence before experiencing a final stage of modest upwarping near the coast. There has been remarkably little landform change under the stable, cold, polar conditions of the last $15 \mathrm{~m} . y$. It is difficult to explain the Sirius Group deposits, which occur at high elevations in the area, if they are Pliocene in age. Overall, denudation may have removed a wedge of rock with a thickness of over $4 \mathrm{~km}$ at the coast declining to $1 \mathrm{~km}$ at a point 75 $\mathrm{km}$ inland, which is in good agreement with the results of existing apatite fission track analyses. It is suggested that denudation reflects the differences in base level caused by high elevation at the time of extension due to underplating and the subsequent role of thermal uplift and flexural isostasy. Most crustal uplift $(2-4 \mathrm{~km})$ is inferred to have occurred in the early Cenozoic with $\mathbf{4 0 0}$ $\mathrm{m}$ of subsidence in the Miocene followed by $300 \mathrm{~m}$ of uplift in the Pliocene.
\end{abstract}

\section{Introduction}

The aim of this paper is to relate geomorphological evidence of landscape evolution to the tectonic processes in the Dry Valleys of the Transantarctic Mountains. Like the Drakensberg Mountains in southem Africa and the Great Dividing Range in Australia the Transantarctic Mountains consist of an eroded plateau edge characteristic of high-elevation passive continental margins [Gilchrist and Summerfield, 1990]. Understanding the landscape evolution of the mountains is important because it can be used to constrain various geophysical models of the tectonic processes associated with such margins. The tectonic history of the Transantarctic Mountains is intimately involved in a debate about the stability of the East Antarctic Ice Sheet. Although our new interpretation of landscape evolution has implications for the

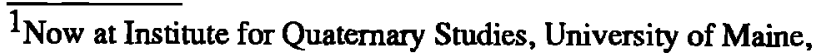
Orono.
}

Copyright 1995 by the American Geophysical Union.

Paper number 94JB02875.

0148-0227/95/94JB-02875\$05.00 debate, we do not consider the issue in this paper (but see Denton et al, [1993]).

Extending across Antarctica, the Transantarctic Mountains rise to over $4000 \mathrm{~m}$ in the Royal Society Range. The mountains consist of gently tilted blocks of sedimentary rocks (DevonianTriassic Beacon Supergroup) overlying Pre-Cambrian-Devonian basement and are intruded and capped by Jurassic dolerites and basalts. The mountains comprise the uplifted rift flank of the West Antarctic Rift System [Behrendt et al., 1991], which has been periodically active since the separation of Antarctica and Australia [Tessensohn and Worner, 1991].

There is considerable uncertainty about the amount and timing of uplift and the tectonic processes involved. Apatite fission track analysis indicates that there has been about $5 \mathrm{~km}$ of denudation in the Dry Valleys area since the early Cenozoic; denudation rates were high in the early Cenozoic before tailing off [Gleadow and Fitzgerald, 1987; Fitzgerald, 1992; Brown et al., 1994]. This implies that significant local relief existed around 55 m.y. ago and that the rift flank was already elevated with respect to base level, either as a consequence of thermal uplift or underplating or as a result of the rifting of a preexisting, highelevation surface. This interpretation agrees with evidence of limited recent surface uplift as inferred from the elevation of 
undisturbed subaerial Pliocene volcanic cones in Taylor Valley [Wilch et al., 1993a]. A different line of evidence suggests that there has been substantial surface uplift of parts of the Transantarctic Mountains of 1-2 km over the past 2-3 m.y. [McKelvey et al., 1991; Webb et al., 1984; Webb and Harwood, 1987]. This view is based on the existence of the remains of temperate vegetation of presumed Pliocene age (2-3 Ma) in Sirius Group deposits at high elevations. There are some 30 Sirius Group outcrops in the Transantarctic Mountains flanking the Ross Ice Shelf between latitudes $86^{\circ} \mathrm{S}$ and $78^{\circ} \mathrm{S}$ and further outcrops in the high mountains of Southem Victoria Land in the Dry Valleys and the Prince Albert Mountains [Denton et al., 1993; Verbers and Van der Wateren, 1992]. The dating of the deposits depends critically on the age and origin of reworked diatoms thought to have originated in marine basins in East Antarctica and to have been subsequently transported to the mountains by ice. The biostratigraphic age of certain of the diatoms has been confirmed by isotopic dating of a volcanic ash layer in the offshore CIROS-2 core [Barrett et al., 1992]. Several other supporting lines of evidence for recent surface uplift have been collated by Behrendr and Cooper [1991], including the "youthful appearance" of the rift shoulder and the presence of offshore Holocene fault scarps. These various views were synthesized by Fitzgerald [1992] who suggested that crustal uplift of the Transantarctic Mountains in the Dry Valleys area has occurred throughout the Cenozoic but with two accelerated pulses at 55-40 $\mathrm{Ma}$ and 10-0 Ma.

In view of the uncertainty about the timing of the uplift, it is difficult to relate the tectonic evolution of the mountains to the wider processes of plate tectonics. At least two periods of rifting have been inferred from study of the Ross Sea embayment [Tessensohn and Worner, 1991; Cooper et al., 1991; LeMasurier and Rex, 1991]. The first phase began in the Mesozoic (possibly linked to the separation of Antarctica and Australia) and was associated with widespread graben downfaulting and crustal thinning. The second began in the Eocene and was associated with uplift and tilting of the Transantarctic Mountains. One interpretation of the Transantarctic Mountains is that they formed by asymmetric rifting associated with extension and subsidence in the adjacent Ross embayment [Fitzgerald, 1992; Fitzgerald et al., 1986]. According to this structural interpretation the mountains represent an upper plate margin [Lister et al., 1986, 1991]. Also, flexural effects related to the strong lithosphere in East Antarctica, together with lateral heat flow from the adjacent extended West Antarctic lithosphere, may have played a role [Stern and Ten Brink, 1989]. Whichever processes are the most important, one particular problem is why, if there has been significant late Cenozoic uplift, it should have occurred >50 m.y. after the late Mesozoic-early Cenozoic extensional event which formed the margin and the adjacent Ross embayment. Here is a suite of problems concerning the tectonic processes associated with passive continental margins where geomorphology can help constrain the various hypotheses.

The Dry Valleys compose one of the many blocks within the Transantarctic Mountains [Fitzgerald, 1992]. Bounding transform faults underlie Mackay Glacier in the north and Ferrar Glacier in the south (Figure 1). There are several advantages in studying the Dry Valleys block. First, similar fission track denudation profiles from the northern sides of Ferrar and Wright valleys [Fitzgerald et al., 1986] imply that the block has behaved as one unit since the early Tertiary, thus holding constant one variable in landscape evolution. Second, the block contains outcrops of Sirius Group deposits at high elevations ( $2650 \mathrm{~m}$ on Mount Feather), critical evidence which must eventually be accommodated in any explanation. Third, the valleys contain a terrestrial record of surface deposits extending back to the Miocene, thus providing an unprecedentedly long window into mountain evolution. A disadvantage of a study restricted to one block is that any conclusions cannot necessarily be extrapolated to other areas of the Transantarctic Mountains.

There have been two main phases of interest in the geomorphological evolution of the Dry Valleys. The first involved geologists of Scott's and Shackleton's expeditions, whose initial observations on the great age of the landscape and the modest impact of present glaciers make relevant reading to this day [Ferrar, 1907; David and Priestley, 1914; Wright and Priestley, 1922; Taylor, 1922]. The second phase accompanied U.S. and New Zealand activities after the Intemational Geophysical Year in 1957. In numerous papers elaborating the geological and glacial history of the area, a general conclusion was that the main valleys owed their origin to earlier stages of glaciation under more temperate conditions [e.g., Taylor, 1922; Bull et al., 1962; Calkin, 1974a; Denton et al., 1971, 1984; Nichols, 1971; Selby and Wilson, 1971]. This view is consistent with the arguments of Van der Wateren and Verbers [1992] in northem Victoria Land. In addition, there is recognition of the particular role of cold desert agents of erosion. For example, Selby [1971, 1974] recognized the prevalence of straight rectilinear slopes and tentlike ridges which he attributed to salt weathering and wind deflation characteristic of this type of frigid, arid environment. The characteristic slope angles were also related to rock strength characteristics [Augustinus and Selby, 1990]. All these slopes were thought to be wearing back the initial, steeper, glacial trough sides and cirques.

This paper puts forward a new interpretation of the geomorphology. The key conclusions relevant to the landscape evolution are as folows.

1. The landscape is relict, and with the exception of a few glacial landforms there has been negligible slope evolution since the Miocene.

2. The landscape is essentially fluvial, with escarpments and planation surfaces at high elevations and river valleys (the Dry Valleys) dissecting the mountains.

3. Glacial modification of the landscape has been relatively minor and selective.

This new interpretation gives an insight into the long history of base level and environmental change, which in tum constrains models of the tectonic evolution of this part of the Transantarctic Mountains.

\section{Approach and Assumptions}

The crux of our approach was landform mapping at a scale of 1:250,000. The resulting map has been published, together with an explanation of the methods and landforms, by Denton et al., [1993]. A sample covering Wright Valley, Taylor Valley, and the 


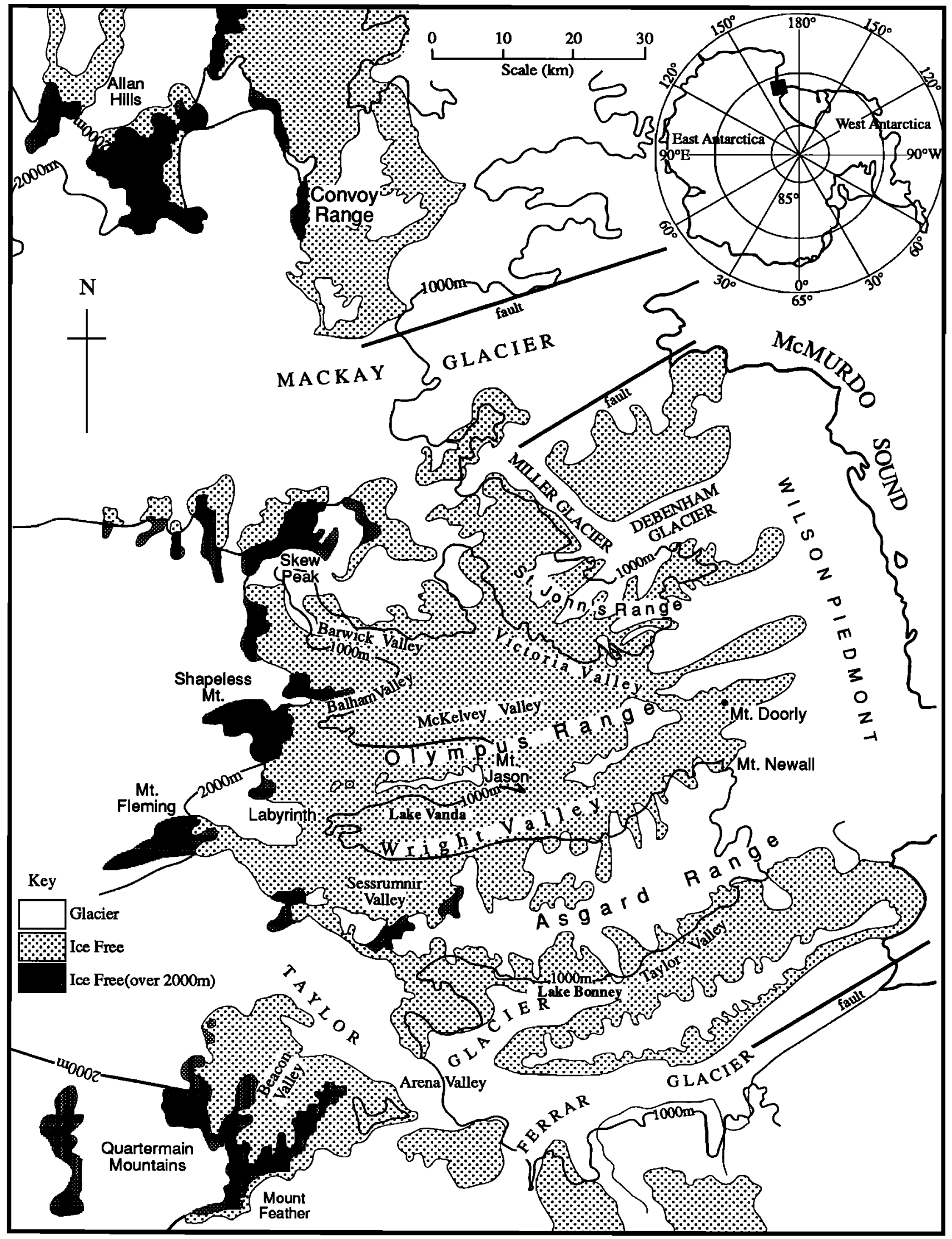

Figure 1. Location map showing the main valleys and bounding transform faults in the Dry Valleys, Antarctica. The faults are taken from Fitzgerald [1992]. 


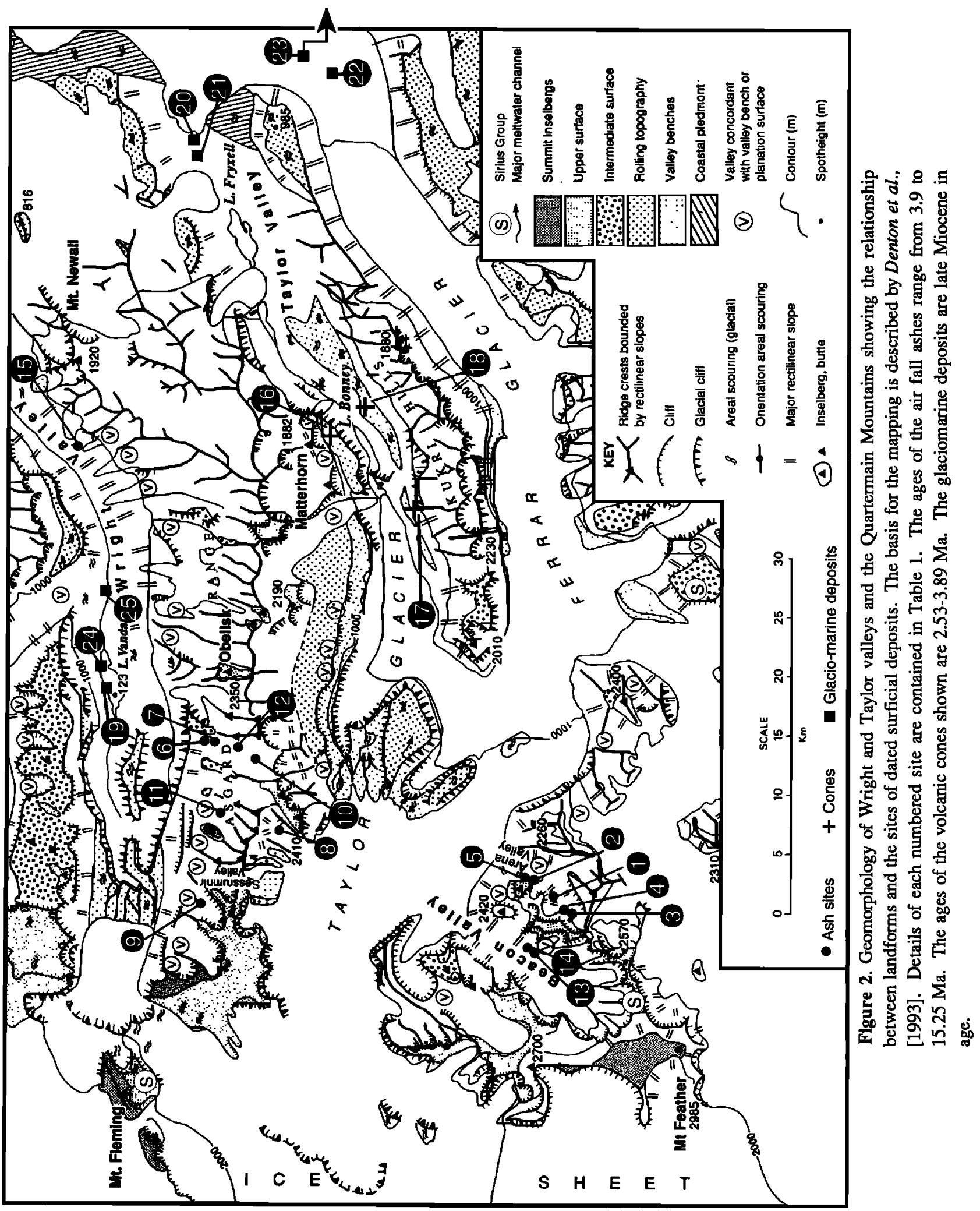




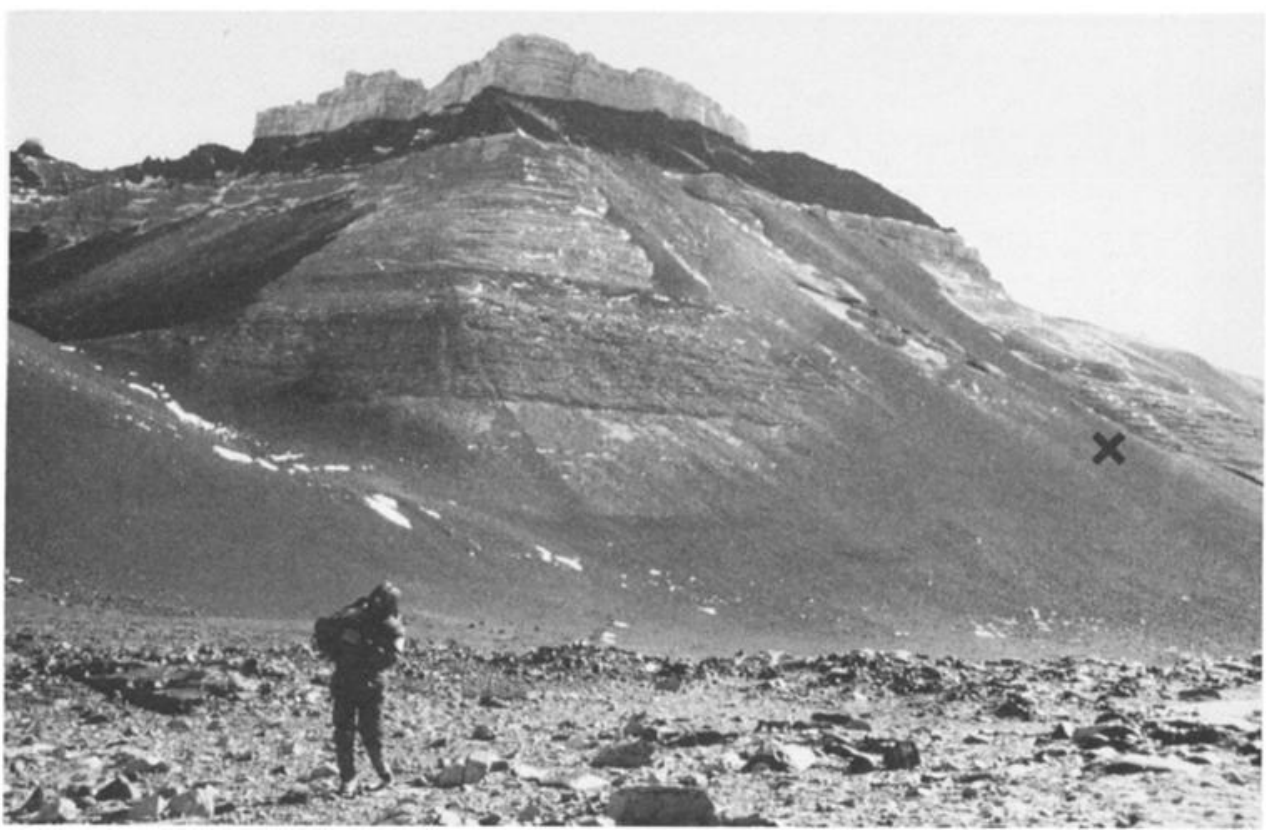

Figure 3. Rectilinear slopes topped by an upper cliff on the flanks of Arena Valley. The patch of remnant regolith mantle in the upper left contains buried ventifacts and stones with desert varnish. The cross on the slope to the right shows the site of an ash fall deposit which occurs in the regolith. The ash (Table 1, site 2) is $8.5 \mathrm{Ma}$ and has survived on a slope of $28^{\circ}$.

Quartermain Mountains is reproduced in Figure 2. A key assumption in any such morphological analysis is that different slope forms and associations can be recognized and used to infer past environmental conditions. For example, the implication is that a landscape of buttes comprising rectilinear slopes topped by steep cliffs and rising abruptly above a flat-lying plain reflects not only structural control but also the operation of a particular assemblage of processes (Figure 3). Rectilinear slopes and cliffs reflect the balance between rock strength and processes which are able to remove any weathered material made available [Selby, 1993]. The surrounding plain is the result of processes which are sufficiently powerful to remove any weathered debris supplied from the adjacent slopes. The sharper the angle between rectilinear slope and plain, the more effective the contrast between rates of slope weathering and the transport processes on the plain. The form of such landscapes is influenced by climate, lithology, and structure. Climatic conditions most favorable for such landforms are semiarid where episodic floods and the lack of deep absorbent regoliths mean that transport processes dominate over weathering. In terms of lithology, the presence of a rock such as sandstone, which breaks down into granular material, favors a sharp contrast between rates of weathering and rates of transport. In addition, geological structure can influence directly the form of cliffs and plains; it can also encourage spring sapping which influences the location and clarity of the junction between valley side and plain. Slopes in more humid environments tend to have more concave and convex elements. This is because of the presence of more vegetation and a deeper regolith and a whole range of different processes which occur in the regolith [Carson and Kirkby, 1972].

It is important to be aware of the limitations of such an approach, the most important of which is equifinality; it is possible that similar slope forms may result from different processes. For example, whereas rectilinear slopes are best developed in arid and semiarid environments, there is no reason why a glacier should not maintain an existing slope if it is able to carry away any debris that falls down the slope. Again, it is easy to confuse the arcuate head of a canyon formed under desert conditions with a glacial cirque when, in the case of the Dry Valleys, glaciers may partly obscure the foot of the cliff. Such limitations must be bome in mind in the subsequent analysis. Nevertheless, each landform is part of a coherent assemblage of landforms, and this helps to constrain the interpretation. Also, in the Dry Valleys where particular landforms are relatively well dated, the approach can place firm constraints on the history of changes in base level and surface processes.

\section{Landforms of the Dry Valleys}

Several landform assemblages can be recognized (Figure 4), and it is useful to summarize the main characteristics.

\section{Planation Surfaces}

There are three main surfaces. The upper surface, formed on Jurassic dolerite, occurs at altitudes of 2000-2400 $\mathrm{m}$ and composes the high ground most distant from the coast (Figure 5). It surrounds the heads of the main valleys and is bounded on its coastward side by an escarpment $500-1200 \mathrm{~m}$ high, the prime feature of the landscape (Figure 6). Large inselbergs, often flattopped and bounded by rectilinear slopes, rise $400-700 \mathrm{~m}$ above the surface to form the highest summits in the area, such as Mount Feather $(3011 \mathrm{~m}$ ) and Shapeless Mountain $(2739 \mathrm{~m})$. The surface has a relief of $10-30 \mathrm{~m}$. The lower, intermediate surface, cut mainly in Beacon sandstone at altitudes of $1700-1850 \mathrm{~m}$, is 


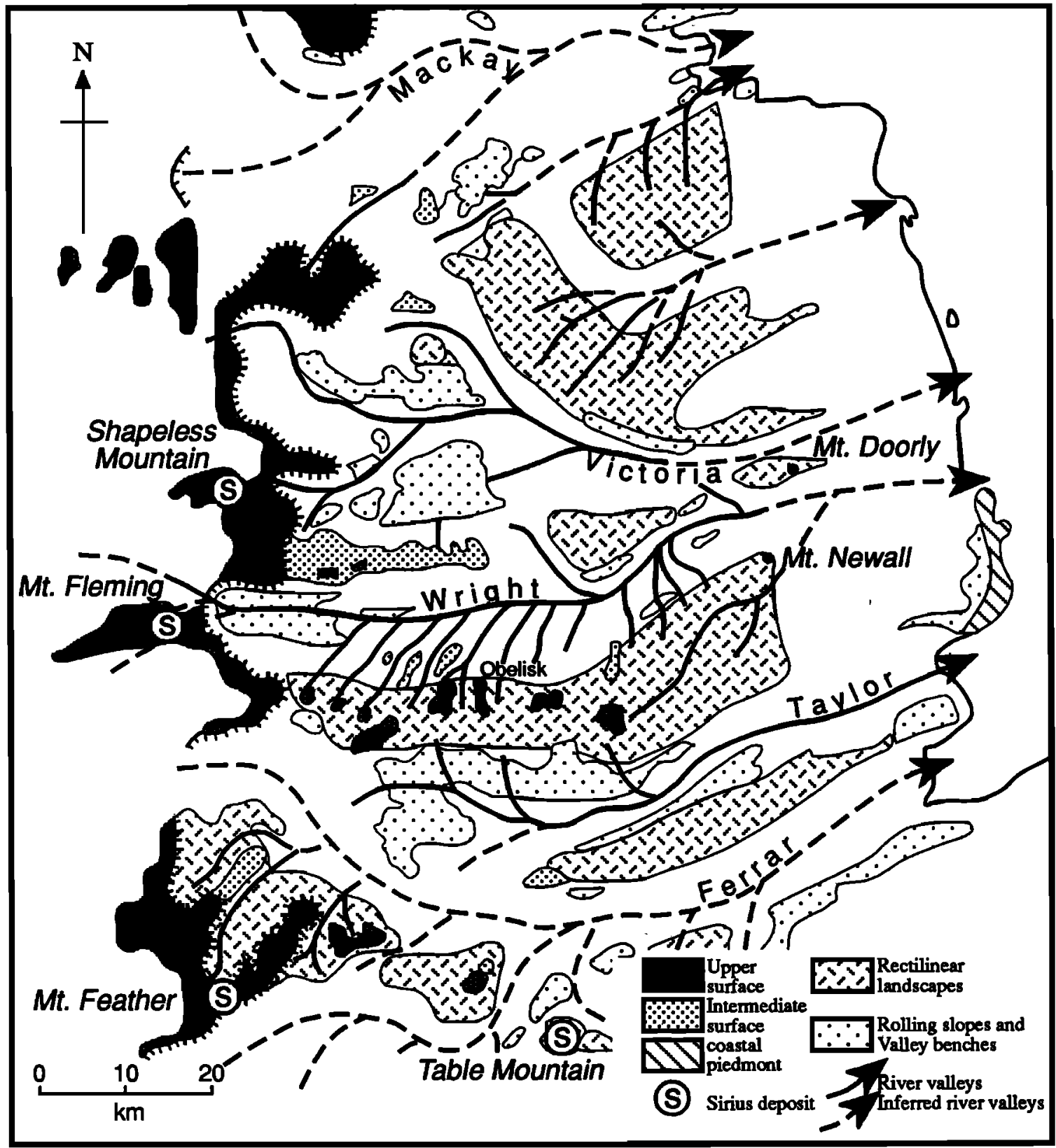

Figure 4. Map showing the distribution of the main landscape types and the relationship to the integrated pattern of river valleys. The upper surface in the west and its fronting scarp give way to dissected mountain landscapes toward the coast.

patchy and occurs most clearly in the vicinity of the Asgard and Olympus Ranges, whose summits are remnants of the upper surface. These ranges comprise inselbergs and buttes which show a progressive change from plateau remnant near the main scarp to isolated buttes farther away. A less extensive surface fringes the coast and rises gently from sea level to altitudes of less than 200 m. It is separated from the intermediate surface by a major escarpment and is cut mainly in granite. Inselbergs with rounded tops, also cut in granite, rise above the surface.

The surfaces and associated inselbergs and buttes are erosional rather than tectonic features. This can be illustrated in the case of the Quartermain Mountains where an uninterrupted, layered rock structure extends beneath both the upper surface and the upstanding inselberg of Mount Feather. Also, a remnant of the intermediate surface cuts across granite basement and dolerite immediately west of Mount Newall. However, structure influences the morphology of the surfaces. For example, the upper surface is underlain by a prominent dolerite sill. Also, irregularities in the surface, for example surrounding the buttes of the Olympus Range, are the result of planation crosscutting the gentle dip of underlying thin beds of sandstone.

\section{Valleys}

The valleys are the main landforms of the area and extend from west to east (Figure 4). There are several noteworthy features. 
W E

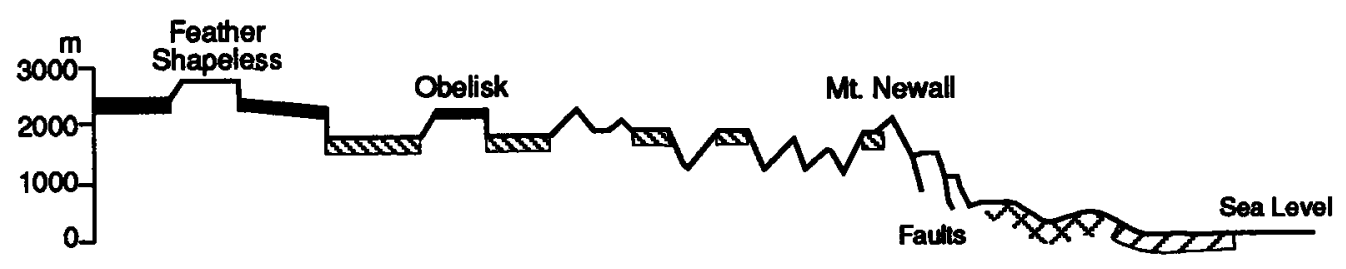

S
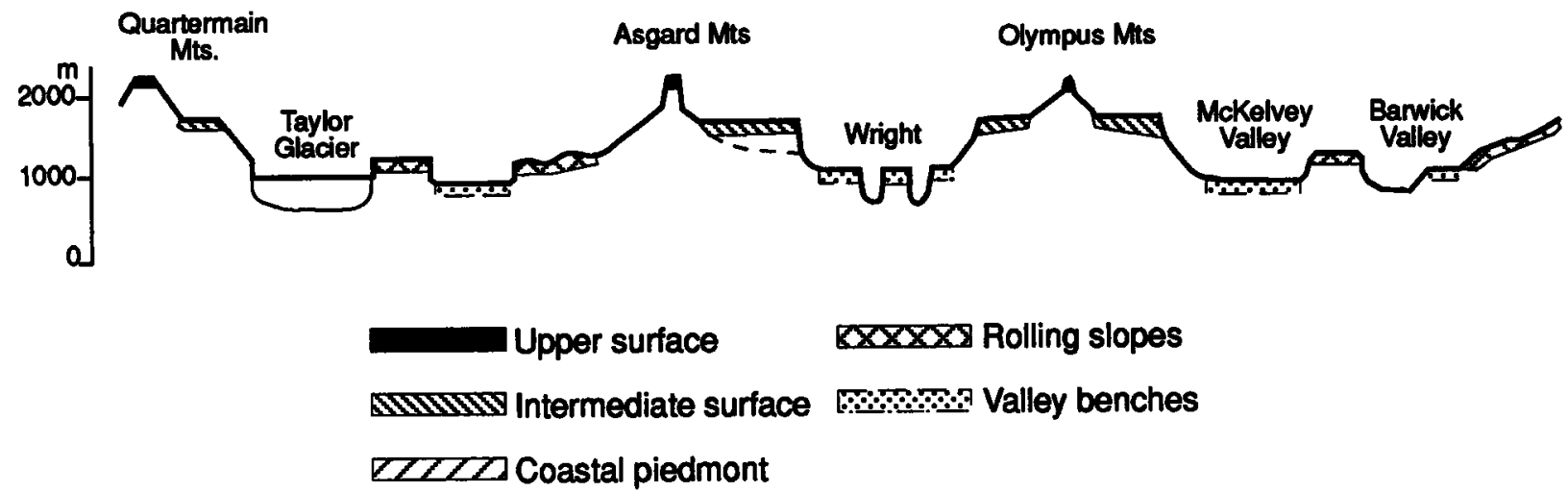

RXXXX8 Rolling slopes

Valley benches

Figure 5. Schematic cross section showing the relationship between the various landscape types: (top) from the inland upper planation surface to the sea and (bottom) from south to north across the main valleys.

1. The valleys from an arborescent network indicative of fluvial action. The best example is the Victoria Valley System, but the pattern is also clear in the case of the Wright and Ferrar Valleys. All continue to the coast, the Wright and Victoria Valleys extending beneath the Wilson Piedmont [Calkin, 1974b].

2. Several valleys are sinuous. The best examples are central Taylor Valley (Figure 7) and lower Wright Valley.
3. The valleys are cut down to near, or below, sea level. The Ferrar, Taylor, Debenham and Mackay Valley mouths are below sea level, while part of the sinuous central Taylor Valley is $90 \mathrm{~m}$ below sea level [Mudrey and McGinnis, 1975].

4. Several deeper valleys have gently sloping, elevated valley benches. The best examples occur on either side of central Taylor Valley where the bench is often terminated by a cliff

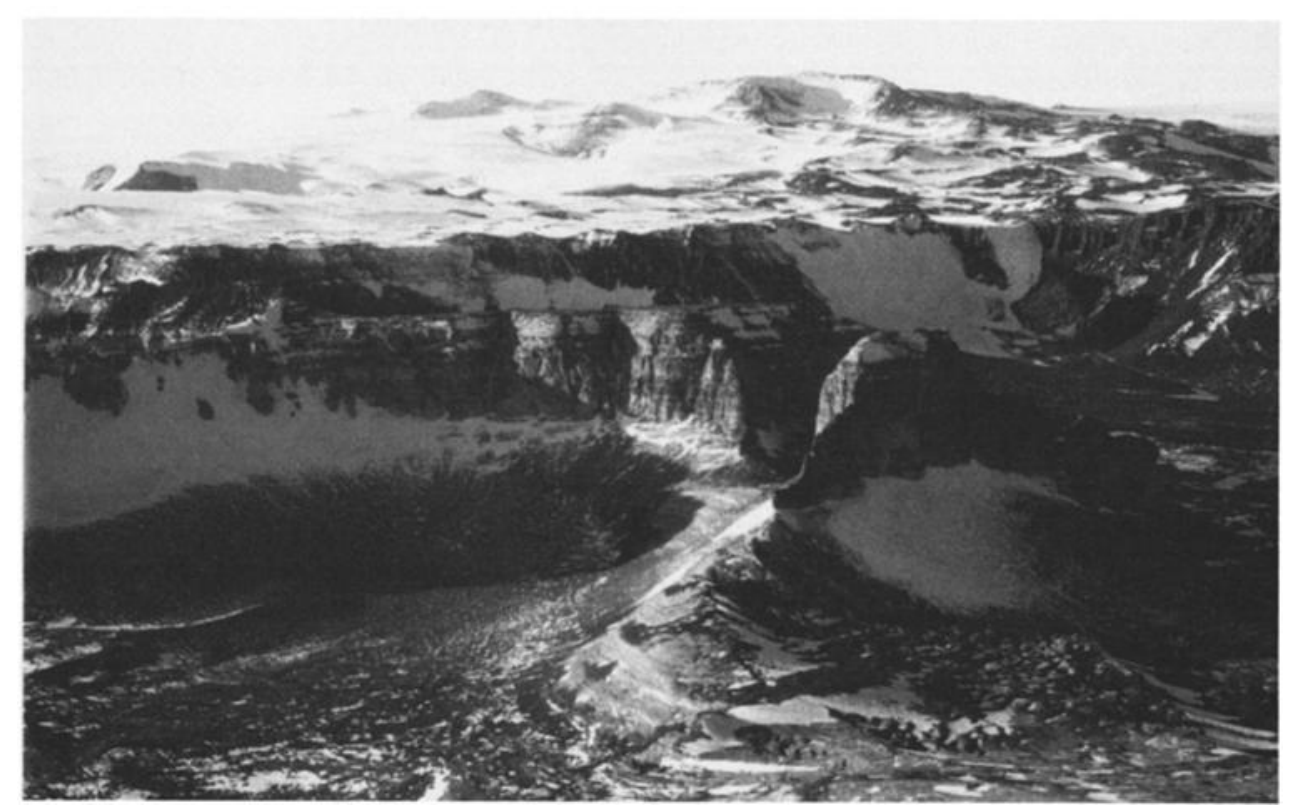

Figure 6. The upper planation surface bounded by a prominent escarpment in the Olympus Range. The inselbergs and buttes of the Olympus Range (foreground) are remnants of the upper surface. Shapeless Mountain (background) rises above the upper surface. 


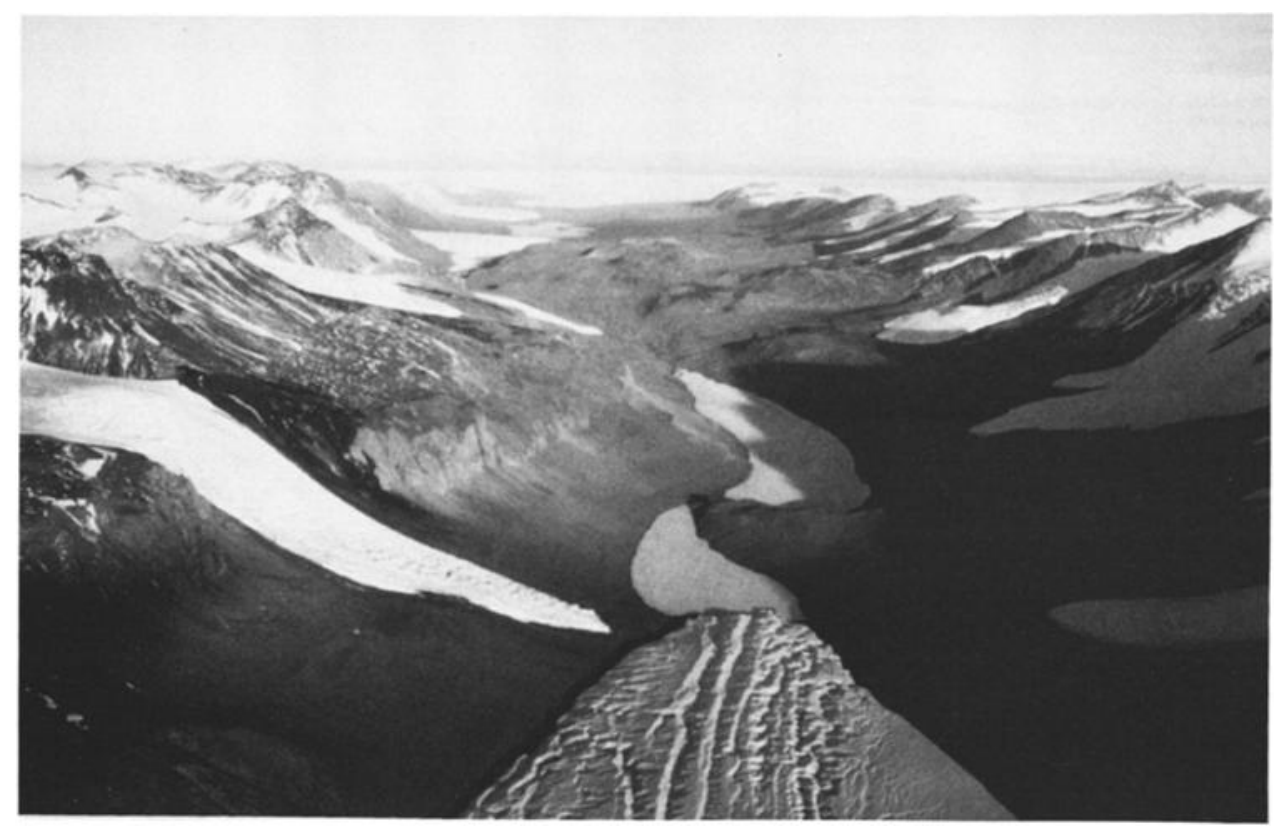

Figure 7. Central Taylor Valley viewed toward the sea showing the valley benches truncated in places by glacial cliffs. The sinuous nature of the inner valley is brought out by the shape of Lake Bonney which extends from the snout of Taylor Glacier (foreground). A dark volcanic cone can be seen on the bench to the left.

(Figure 7). Other benches flank Ferrar and Mackay Valley systems and parts of Wright and Victoria Valleys. The bench cut by the Labyrinth at the head of Wright Valley is a particularly good example (Figure 8).

5. All major valleys have high-level tributaries. Some of these are graded to the intermediate surface, as in the Asgard Range, and others are graded to the level of the valley benches. There is some asymmetry in that tributaries form a subparallel pattern on the southern side of upper Wright and Taylor Valleys.

6. Taylor, Wright, and Victoria Valleys have a reverse slope, and present-day meltwater streams drain inland into lakes. In the case of Wright Valley the amplitude of this reverse slope is at least $147 \mathrm{~m}$ between the exposed lower valley and the surface of Lake Vanda (Figure 8).

\section{Rectillnear Slopes}

Straight slopes cutting bedrock at angles of $26-36^{\circ}$ are characteristic and occur in three situations. The first includes the slopes of inselbergs, buttes, canyons, and the main escarpment (Figure 3). Here, the foot of the rectilinear slope is marked by a sharp break as it gives way to a flat surface or valley floor. A second association is with dissected mountain ridges and the mountain front. Ridge crests are typically straight with angular plan views and bounded by rectilinear slopes often leading down to glaciers in the intervening valleys. Tors top some ridges. Whenever remnants of the intermediate surface occur, the altitude of the adjacent ridge crests is always lower than the surface, for example in the Kukri Hills, eastern Asgard Range, and the Saint John's Range (Figure 1). A third association of rectilinear slopes is with the main valleys in the area. The sides of the Ferrar Glacier valley seaward of the point of flotation, Taylor, Wright, and the Victoria/Barwick/McKelvey Valleys are rectilinear. The main difference with elsewhere is that the rectilinear slopes tend to be less steep and to lead down to concave slopes in the valley bottom.

\section{Rolling Topography}

This landscape type, comprising convex-concave slopes, occurs in two situations. The first is on the flanks of the inner Taylor and Victoria Valleys, where it lies below $1800 \mathrm{~m}$ and the intermediate surface and yet above the valley benches. The second situation comprises the low-lying hills between the main mountain front and the coastal plain.

\section{Glacial Landforms}

The major glacial features are straight, cliffed troughs, such as those occupied by the Mackay and Miller glaciers and the inland flanks of Ferrar Glacier. Other glacial cliffs truncate the valley benches in Taylor, Wright, and lower Victoria Valleys. All are marked by their large scale, association with straightened valley sections complete with truncated spurs, and the cliffed termination of the upper rolling or rectilinear ridge landscapes (Figure 8). Central Wright Valley, which is straight and cliffed, has a broad U-shaped valley cross profile. Landscapes of areal scouring which have been roughened by glacial erosion [Sugden, 1974] occur in three main locations: the upper surface, the valley benches, and the rolling slopes and low-lying plain near the coast. Cirques and couloirs occupied by small glaciers occur patchily throughout the area. Typically, they form small arcuate basins excavated into a rock rectilinear slope beneath an upper free face. Impressive channel systems, sometimes over $50 \mathrm{~m}$ deep, occur throughout the area. The anastomosing pattern, up-and-down long profiles, ungraded confluences, and association with gigantic potholes all point to the role of subglacial meltwater in their formation [Sugden et al., 1991]. They occur near the heads of the main valleys, for example, the Labyrinth in upper Wright Valley 


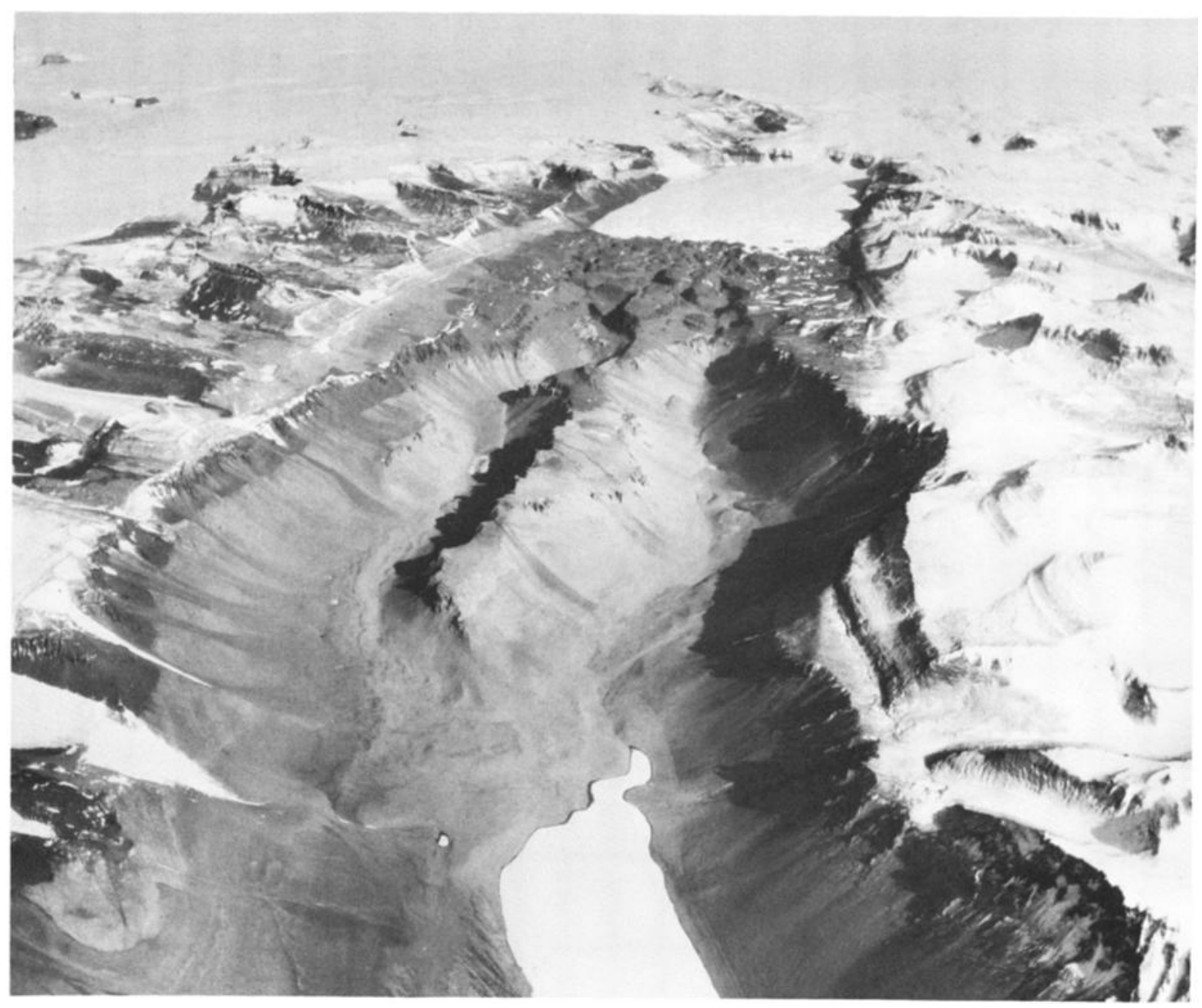

Figure 8. View up Wright Valley showing Lake Vanda (foreground), the valley bench incised by the channels of the Labyrinth, and the overdeepened trough of Wright Valley. The flanks are bounded by the intermediate surface, bearing the inselbergs and buttes of the Olympus and Asgard ranges. U.S. Navy photograph TMA 1564.

(Figure 8), the head of McKelvey Valley, and the Miller glacial trough. They are also associated with cols in the Asgard Range, notably in Sessrumnir Valley. They are cut into both dolerite and sandstone.

Glacial deposits mantle many of the gentler slopes and reflect a remarkably complex story of deposition, subsequent erosion, and transport [Marchant et al., 1993b, c]. A particularly significant deposit is the Sirius Group. Within the Dry Valleys area it is known in four locations (Figures 2 and 4). Three of these are restricted to the flanks of inselbergs which rise above the upper surface, namely, Mount Feather [Brady and McKelvey, 1979]. Mount Fleming, and Shapeless Mountain [McKelvey, 1991]. The fourth occurs on Table Mountain, overlooking the south side of Ferrar Glacier [Barrett and Powell, 1982]. The deposits consist mainly of tills typical of warm-based glaciers, containing faceted and striated stones within a fine-grained matrix.

\section{Age of the Landforms}

Dating of rocks and organic remains associated with the various landforms places constraints on the sequence of landscape evolution. The ages of the oldest sediments and their stratigraphic settings are summarized in Table 1 , while the relationship of the deposits to the landforms is shown in Figure 2. The Dry Valleys themselves are long known to have been relict since glacial and marine sediments in their seaward mouths are Miocene in age. At the mouth of Ferrar Glacier the base of the CIROS-2 core revealed glaciomarine sediments dated on - biostratigraphic grounds as older than $4.5 \mathrm{Ma}$ [Barrett and Hambrey, 1992]. Microfossils at the base of the Dry Valleys Drilling Project (DVDP 11) core drilled into sediments at the mouth of Taylor Valley are late Miocene in age [McGinnis, 1981; Ishman and Rieck, 1992]. The ${ }^{87} \mathrm{Sr} /{ }^{86} \mathrm{Sr}$ ratios on shells in the Jason glaciomarine diamicton in central Wright Valley suggest ages of $9 \pm 1.5 \mathrm{Ma}$, while in situ shells in the Prospect Mesa gravels are aged $5.5 \pm 0.4 \mathrm{Ma}$ [Prentice et al., 1993]. All these dates suggest that the valleys were already excavated before bcing flooded by the sea during the Miocene.

The flanks of the valleys can also be shown to be old. In Taylor Valley there are numerous small volcanic cones and associated scoria deposits which have erupted on to the valley benches and the lower glacially moulded slopes (Figure 7). 

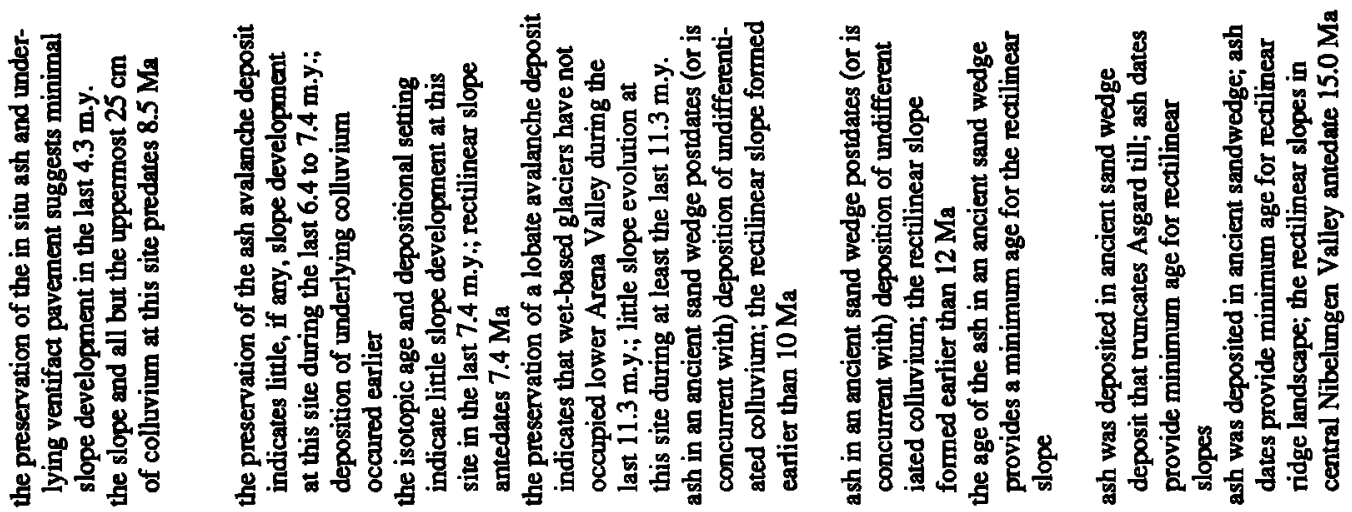

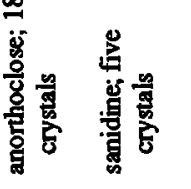

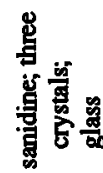

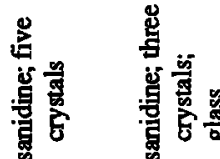

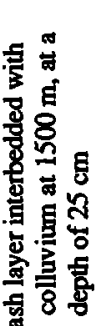

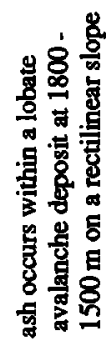

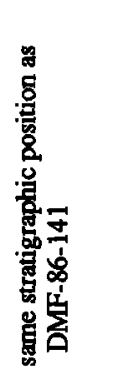

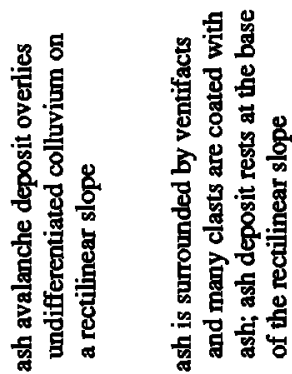

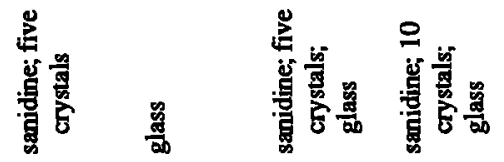

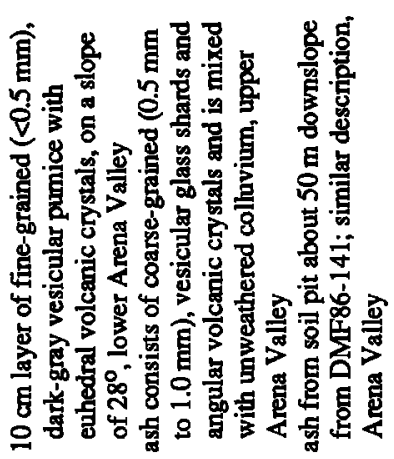

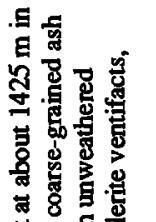

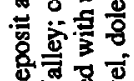

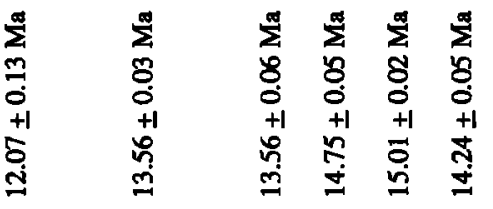

焉

$\sum_{0}^{\pi}$
$\vdots$
0
+1
0
0
0

噌

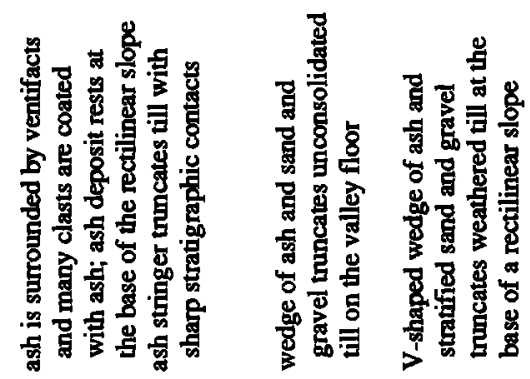

营

$>$

空

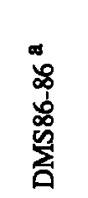

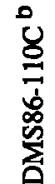

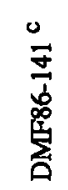

商

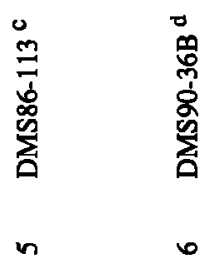

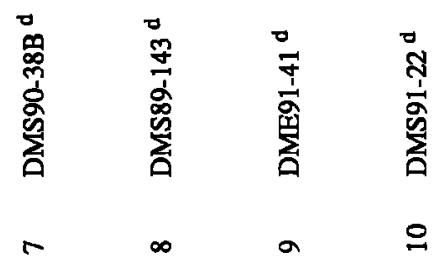



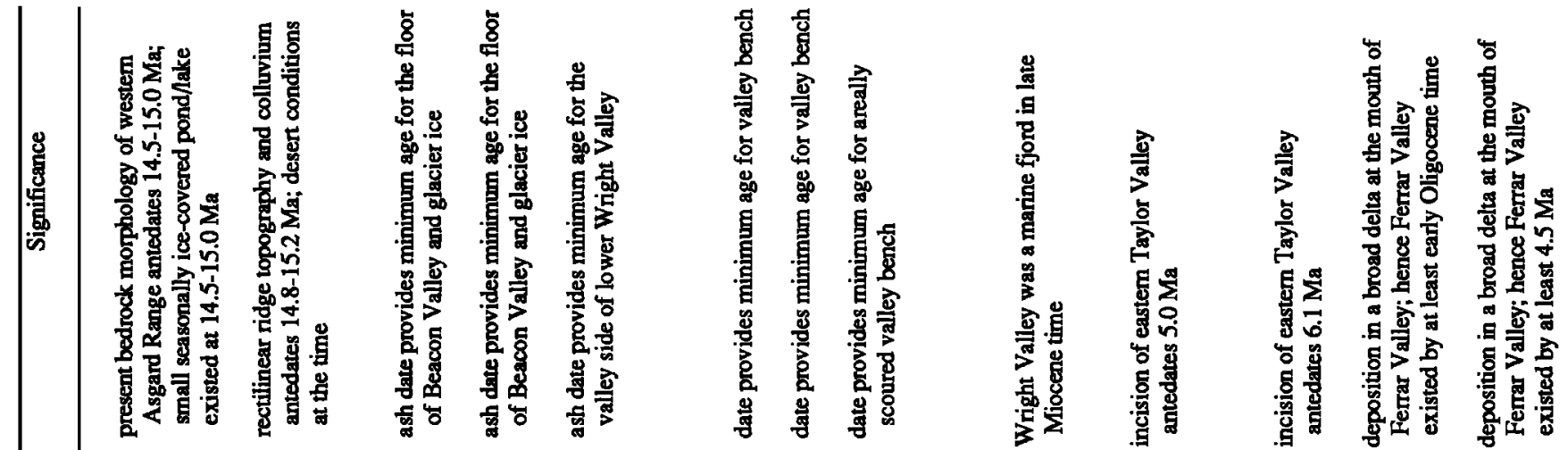

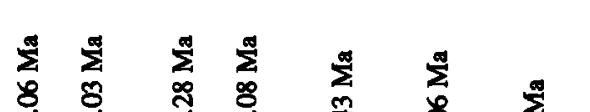

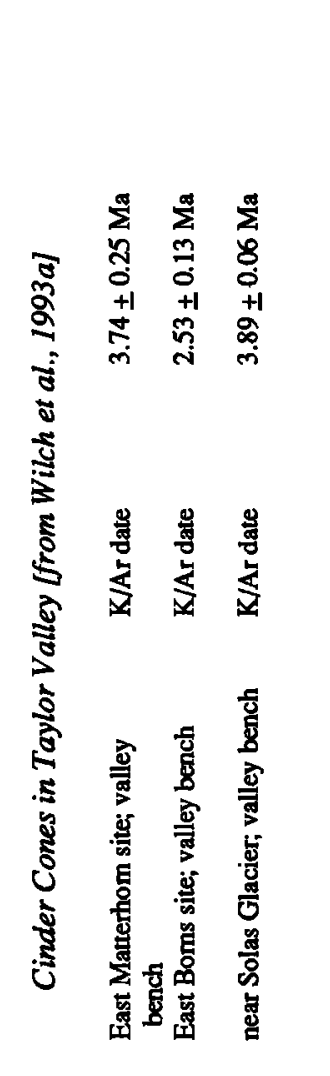

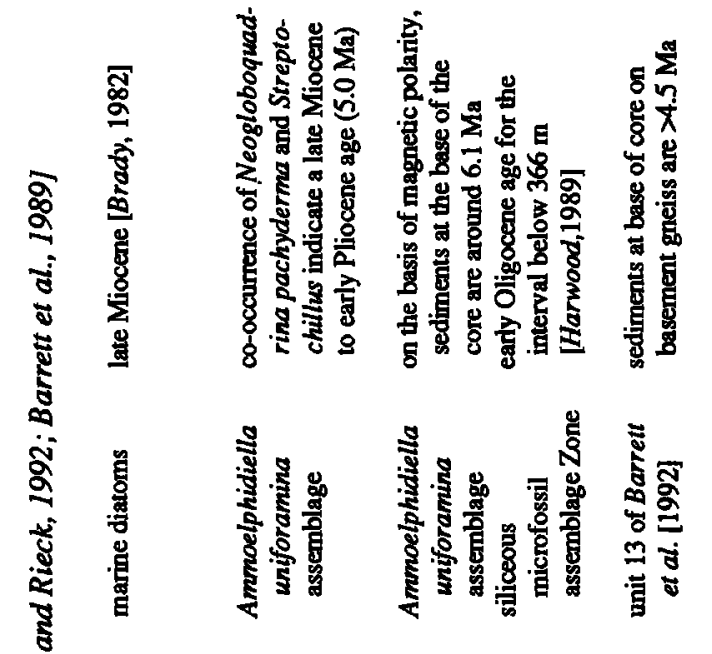

蛋

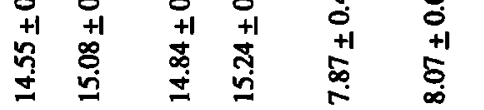

$\exists$

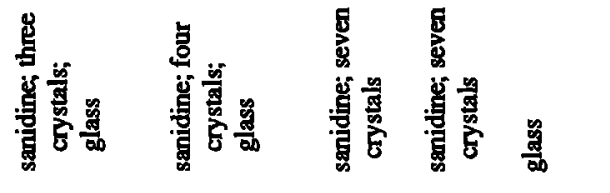

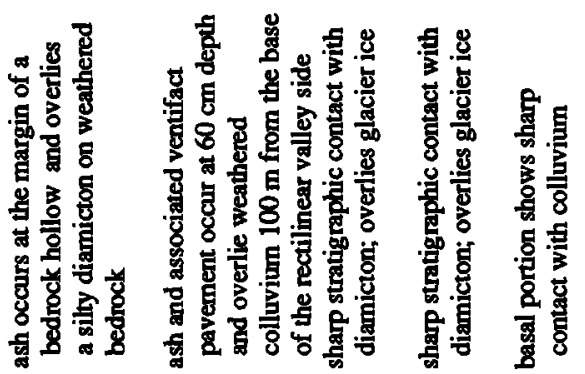

हू

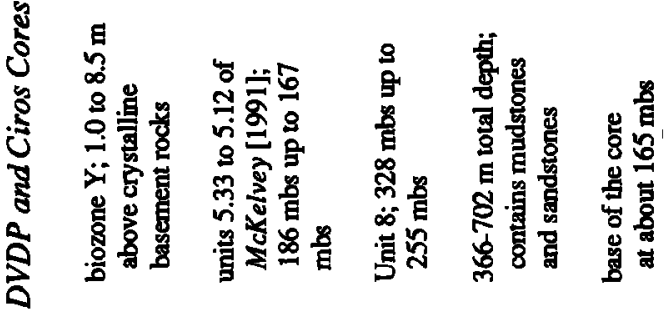

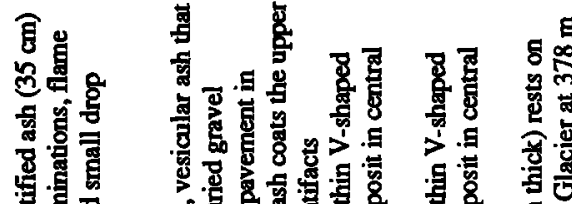

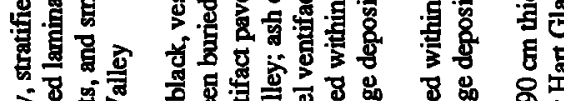

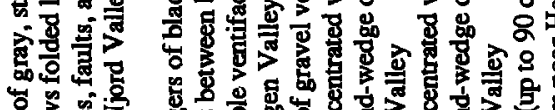

额它

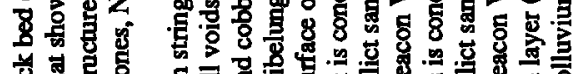

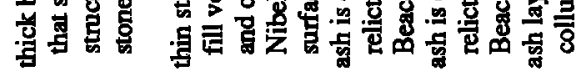

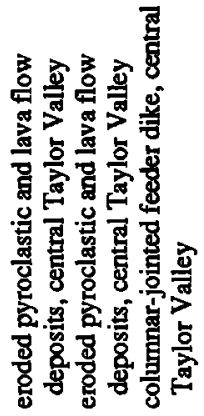

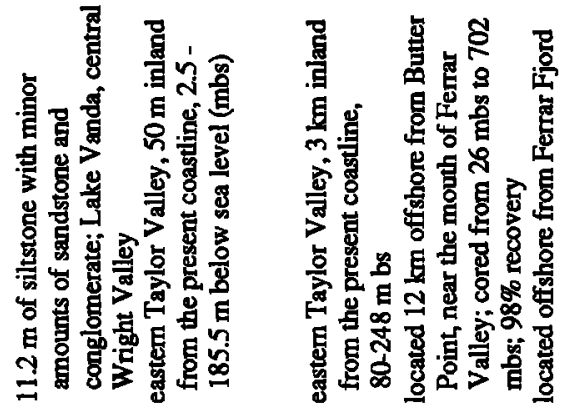

$\stackrel{\infty}{\rightarrow}$

2 ำ

$\overline{\text { ส }}$

กิ 


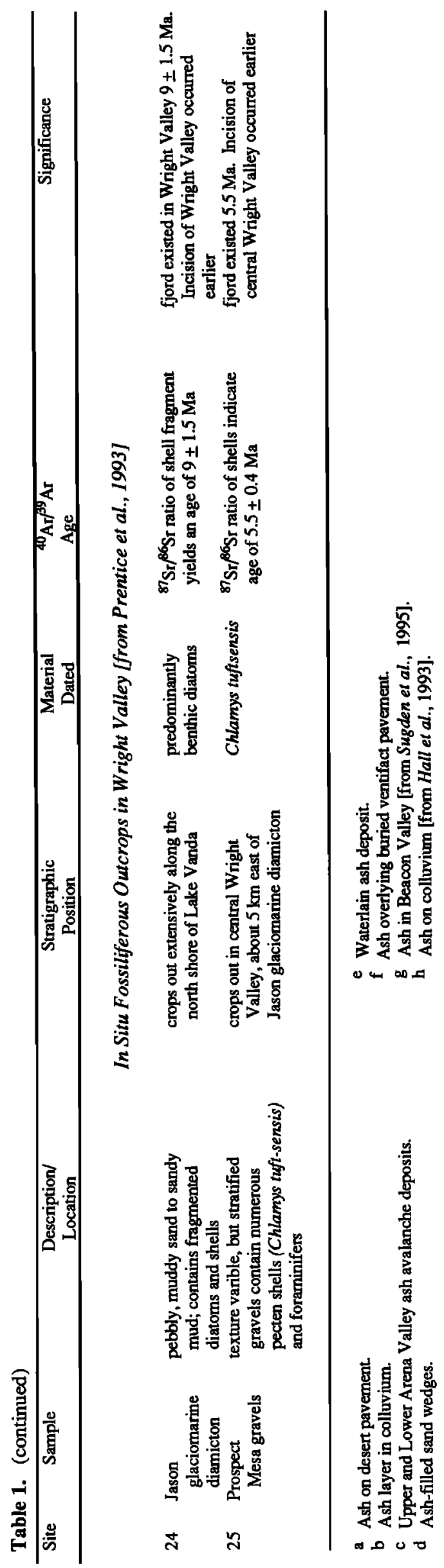

Fourteen eruptions range in age from 1.5 to $3.89 \mathrm{Ma}$ and demonstrate that the underlying bedrock slopes are older than this [Wilch et al., 1993b]. Details of three eruptions are listed in Table 1 (sites 16-18). In Wright Valley there are terminal moraines associated with tributary glaciers forming loops on its southern flank, which are $>3.7 \mathrm{Ma}$ in age [Hall et al., 1993]. Their preservation demonstrates that there has been little morphological change subsequently.

The great age of the slopes of the Quartermain and Asgard ranges can be established by their association with in situ volcanic ashes trapped in frost cracks, tills, regolith and ash avalanche cones [Marchant et al., 1993a, b, c). The ashes have been dated by laser fusion ${ }^{40} \mathrm{Ar} /{ }^{39} \mathrm{Ar}$ analysis of single feldspar crystals. There is good evidence that the ashes accumulated as a result of direct airfall or by avalanching associated with the settling of the ash, rather than by desert aeolian processes. This is demonstrated by the physical characteristics of the ash, notably the concentration, coarse grain size, poor sorting (bimodal) and presence of angular shards, all characteristics of primary ashfalls with limited transport [Fisher and Schminke, 1984]. It is also confirmed by the distinct geochemistry of individual deposits and the consistency of age of individual crystals within a deposit [Marchant et al., 1995]. The ashes are remarkably unweathered and contain less than $10 \%$ clay-sized grains, while individual volcanic crystals show few signs of chemical weathering. Dating of unweathered grains shows that the deposits are Miocene in age. Table 1 lists the details of 15 sites and reveals a range of ages from $3.9 \mathrm{Ma}$ to $15.25 \mathrm{Ma}$.

The ashes occur on high-altitude valley floors, rectilinear slopes, and even in minor lake hollows. One significant site is shown in Figure 3, where ash has survived in regolith on a rectilinear slope of $28^{\circ}$ since it was deposited at the time of an eruption $8.5 \mathrm{~m}$.y. ago. Other ashes are preserved in thin regolith or in ash avalanche cones. The implication is that the slopes in the Asgard and Quartermain range had achieved their present detailed form by the mid-Miocene and have remained essentially unchanged for 15 m.y. This conclusion is consistent with the presence of Pliocene ash in the CIROS-2 borehole in Ferrar Glacier valley, as recorded by Barrett et al., [1992].

It is important to note the association between Pliocene Sirius Group deposits and the higher surfaces and associated inselbergs. There is an implication that these high-level surfaces, like the overlying deposits, may be Pliocene in age, as argued by Van der Wateren and Verbers [1992] in northern Victoria Land. This poses an immediate problem in that they are distinctly younger than the deposits at lower altitudes in the Dry Valleys. At this point in the argument it is worth recalling that the dating of the Sirius Group deposits relies on biostratigraphic correlation of diatoms, supported by the dating of volcanic ash in one offshore borehole [Barrett et al., 1992]. At present there are no published, direct exposure age or ash dates from the deposit itself. Moreover, there is debate about the age and significance of the Nothofagus fossils in the deposit [Burckle and Pokras, 1991], the significance of the diatoms [Burckle, 1995] and the climatic conditions in the area at the time of volcanic eruptions 3 m.y. ago [Marchant et al., 1993a].

There is limited but useful information about the age of 
offshore sediments which relates to the story of landscape evolution. Seismic surveys of the offshore basins reveal the presence of gently seaward dipping sediments thought to have been mainly derived from the rising Transantarctic Mountains [Davey and Christoffel, 1986; Cooper et al., 1991]. The CIROS-1 drill hole penetrated $700 \mathrm{~m}$ into deltaic sediments associated with the Ferrar Glacier. It reached only halfway to the basement but revealed sediments dating from the early Oligocene (36 Ma) to early Miocene. The implication is that the Ferrar Glacier valley was in existence at the time [Barrett et al., 1989]. Presumably, the lower, equally thick deposits reflect deposition during the Eocene. There are minimal thicknesses of Miocene and Pliocene sediments. The presence of basement granite from the earliest Oligocene has been interpreted to mean that some $2.5 \mathrm{~km}$ of Beacon Supergroup had been eroded from the adjacent mountains by about $36 \mathrm{Ma}$.

Finally, it is worth noting the oldest deposits associated with the present landforms. Jurassic basalts (Kirkpatrick basalt) erupted into a depression on a land surface which is preserved today on an inselberg rising above the upper surface in the Allan Hills [Ballance and Watters, 1971]. The Allan Hills are the equivalent of inselbergs such as Mount Feather and Mount Fleming and lie on the northern flank of Upper Mackay Glacier (Figure 1).

\section{Landscape Evolution}

The nature, spatial relationships, and age of the various landform associations provide the basis for reconstructing the sequence of landscape denudation and the climatic environments involved. We assume that the high upper and intermediate planation surfaces are the oldest elements of the landscape. Since inselbergs associated with the intermediate surface comprise parts of the upper surface, it is tempting to suggest that the lower of the two surfaces is younger. However, it is quite possible that both surfaces formed contemporaneously but with their detailed morphology influenced by lithology. The valleys and dissected rectilinear ridge landscapes are cut into the two surfaces. This is illustrated by the way the surfaces are progressively dissected toward the coast and by the way the remnant inselbergs and peaks lie at comformable or slightly lower altitudes than the adjacent surface from which they have been eroded.

The downcutting seems to be fluvial in origin. This is illustrated by the integrated pattern of the tributaries, the sinuosity of the main valleys, the presence of valley benches, and the way the valleys are graded to near sea level. The main valleys and their associated rolling slopes and valley benches have been incised most deeply, as is illustrated by the way tributary valleys are left hanging above the main valley floors. Finally, glacier ice has covered all slopes from the highest upland surface to valley floors and the coastal lowland. Glacial erosion has been significant in straightening and deepening preexisting sinuous valleys but has been minimal on some of the higher interfluves, such as the Asgard Range, where forms due to glacial erosion are rare.

The intermediate surface reflects scarp retreat, probably under semiarid conditions, as argued by Denton et al., [1993]. It is useful to summarize the arguments in favor of such an interpretation. First, the presence of escarpments progressively consuming higher surfaces reflects denudation by parallel slope retreat. Such a pattern of denudation is well known in semiarid environments where the key process is the power of surface wash in creating pediplains and removing regolith from upstanding slopes [Carson and Kirkby, 1972]. Second, the detailed form of the slopes is characteristic of semiarid conditions, notably the buttes bounded by rectilinear slopes, for example in the Olympus Range, and the presence of box canyons at the head of a dendritic river valley system, as, for example, in Beacon Valley, Quartermain Mountains and the Asgard and Olympus Ranges. Third, buried desert surface ventifacts occur within the regolith found on some rectilinear slopes (Figure 3), a finding which is consistent with an origin under semiarid conditions [Marchant et al., 1993b,c].

Semiarid conditions may also have marked the initial stages of downcutting as suggested by the rectilinear ridge landscapes and rectilinear slopes of the mountain front. Possibly, further downcutting saw a change to more humid conditions which allowed the creation of the rolling slopes in the inner reaches of the main valleys and the gentle slopes of the valley benches, but this morphological change could be related to lithology as the valleys increasingly cut into basement rocks. The rivers were able to grade their main valleys to near sea level some distance from the coast. In the case of Lake Bonney, which today occupies a river-cut, sinuous section of Taylor Valley, the valley was close to sea level some $35 \mathrm{~km}$ from the coast (Figure 7).

A change to cooler conditions is indicated by evidence of glaciation at a wide variety of altitudes. Cold polar conditions have existed since the main elements of the landscape were formed. This is implied by the preservation of the relict regolith on slopes of $26-30^{\circ}$ for millions of years [Marchant et al., 1995]. It is also demonstrated by the minimal erosional effects of valley glaciers flowing into the main valleys. For example, the glaciers originating in the Asgard Range and flowing into Wright Valley have failed to excavate troughs, suggesting that their bases have remained below the pressure melting point since their formation. They are also fringed by relatively small moraines derived from valley side debris, and these represent the total load over at least 3.7 m.y. [Hall et al., 1993]. Such small debris loads are typical of glaciers in a cold polar environment.

\section{Relationship to Structure and Tectonics}

There is good evidence of differential denudation, with a maximum near the mountain front and less inland. This is well displayed by the tilt of the basement surface of Ordovician or Devonian age, known as the Kukri "peneplain", which is assumed to have been approximately horizontal at the time of its formation and is now overlain by Beacon Supergroup sedimentary rock [Gunn and Warren, 1962]. It is exposed in the innermost reaches of Taylor and Wright valleys where it is now at an altitude of 700 $\mathrm{m}$ and $900 \mathrm{~m}$ respectively and dips inland at $23^{\circ}$. It rises in discrete blocks towards the coast, reaching altitudes of $1800 \mathrm{~m}$ in the vicinity of Mount Newall. The main mountain front itself is downfaulted [Fitzgerald, 1992]. Uniform rectilinear slopes truncate the fault lines and are associated with valley incision of the mountain front. Also, the same fault zone cuts across Taylor 


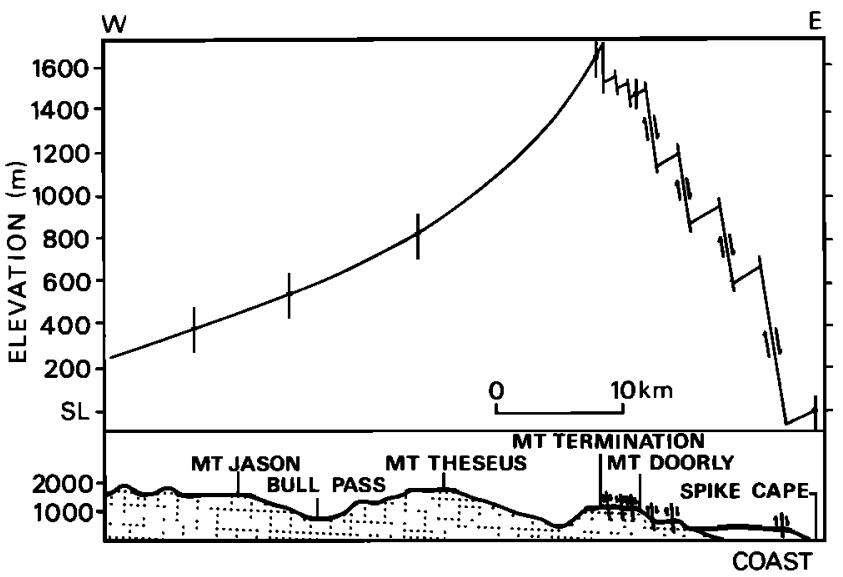

Figure 9. Cross section of the Transantarctic Mountains parallel to Wright Valley showing differential uplift since $55 \mathrm{Ma}$, after Ten Brink and Stern [1992]. The uplift is represented by a preuplift isochron related to a coastal datum. The isochron is derived from apatite fission track analysis and represents the partial annealing zone before uplift [Gleadow and Fitzgerald, 1987].

Valley and truncates the valley benches of the interior. These relationships suggest that the faulting occurred before and during the phase of valley downcutting, but not subsequently.

The overall pattern of the differential crustal uplift can also be inferred from fission track analysis and is shown in Figure 9. The profile, which runs at right angles to the coast through Mount Doorly, represents the distortion of a preuplift, approximately horizontal, isochron in relation to sea level at the coast [Gleadow and Fitzgerald, 1987]. The downthrow of the faults at the mountain front is of the order of $1650 \mathrm{~m}$, approximately the same as the difference in altitude between the intermediate surface and the coastal piedmont. In view of this approximate coincidence, the coastal piedmont could be a downfaulted remnant of the intermediate surface.

It is possible to use the tectonic and structural relationships to estimate the amount of denudation involved. One estimate comes from the fission track analysis. Since the original isochron is thought to have formed in the partial annealing zone at a depth of around 4-5 km, its exposure along the crest of the mountain front implies denudation of around $4-5 \mathrm{~km}$, with progressively lesser amounts inland [Fitzgerald, 1992]. Another estimate comes from the relative elevation of the Kukri peneplain. Assuming that the Kukri peneplain was horizontal and covered uniformly with $3.1 \mathrm{~km}$ of younger rocks $(2.5 \mathrm{~km}$ of the Beacon Supergroup [Barrett, 1981] and about $600 \mathrm{~m}$ of dolerite sills [Hamilton et al., 1965; Gleadow and Fitzgerald, 1987], then one can estimate the amount of denudation from place to place. In Wright Valley the Kukri peneplain declines from $1650-1800 \mathrm{~m}$ at the mountain front to $1050 \mathrm{~m}$ in the vicinity of Mount Jason and $700 \mathrm{~m}$ in upper Wright Valley where it disappears beneath dolerite. Extrapolating the same dip would suggest it is at an altitude of $100 \mathrm{~m}$ beneath Mount Fleming, an inselberg rising to $2400 \mathrm{~m}$. If these approximate figures are used and the altitude of the present summits is allowed for, then there has been denudation of $0.6 \mathrm{~km}$ above Mount Fleming, $1 \mathrm{~km}$ from the upper surface and over 3.1 $\mathrm{km}$ from above the summits of the mountain front and the intermediate surface in the vicinity. At the coast where there is relief of $900 \mathrm{~m}$ in basement rocks, the denudation exceeds 4.0 $\mathrm{km}$. These different methods of calculating amounts of denudation agree closely. Together, they suggest that erosion has removed an irregular wedge of rock more than $4 \mathrm{~km}$ thick at the coast and tapering to less than $1 \mathrm{~km} 75 \mathrm{~km}$ inland.

\section{Model of Landscape Evolution}

It is possible to bring together the various strands of evidence and to present a hypothesis of the evolution of the Dry Valleys which synthesises geomorphology, tectonics and climate. We suggest the area begins as one flank of an extensional rift (Figure 10a). The continental edge has an altitude of $1200 \mathrm{~m}$. Admittedly, this is arbitrary, but $1200 \mathrm{~m}$ seems a realistic altitude for the interior of a large continent, especially in view of the presence of extensive flood basalts which could indicate underplating [Lister et al., 1991]. Also, assuming no differential tectonic movement, this figure has been calculated to have been the initial altitude of westem South Africa on the basis of the volume of offshore sediments [Gilchrist and Summerfield, 1994]. The $1200 \mathrm{~m}$ altitude is higher than the $500 \mathrm{~m}$ assumed by Gleadow and Fitzgerald [1987], but this latter value is admitted to be poorly constrained; it is based on the view that the lowgradient floodplain beneath the Kirkpatrick basalt would have been close to sea level and on analogous situations in Greenland. Such arguments do not necessarily carry weight in escarpment landscapes. Under such circumstances, it is perhaps helpful to bear in mind both estimates as an indicator of the level of uncertainty involved in this initial assumption.

Following extension, scarp retreat associated with pediplanation extended inland from the new base level created at the new coast and along the main river valleys (Figure 10b). The upper and intermediate surfaces may be the result of scarp retreat from two different base levels, perhaps reflecting the original base level at the time of rifting and a subsequent base level fall as a result of some uplift. Altematively, they may reflect the dominant role of a major dolerite sill in interrupting the slope of a single phase of base level change. Either way, the pediplains eroded down to granite basement at the coast and removed at least $3 \mathrm{~km}$ of cover rocks in this location. Modest lowering occurred on the upper surface, perhaps sufficient to create inverted relief whereby the Jurassic basalts, originally extruded in depressions, now capped some of the inselbergs rising above the surface, as in the case of the Allan Hills today. The contrast between the high rates of erosion that would be expected along the scarp and the low rates of erosion on flat surfaces is well described by Gilchrist and Summerfield [1990].

Figure $10 \mathrm{c}$ shows the situation following downcutting of the major river valleys. Valleys have cut into the mountains causing most fretting toward the sea. The intermediate surface is tilted back and has virtually no seaward slope, while the valleys are graded to sea level. Apparently, much of the downcutting accompanied faulting and rock uplift of the mountain front, which would account for a further fall in relative base level. It is likely that glaciers contributed to the widening and straightening of some major valleys.

There followed a period of apparent subsidence sufficient to 
W

(a)

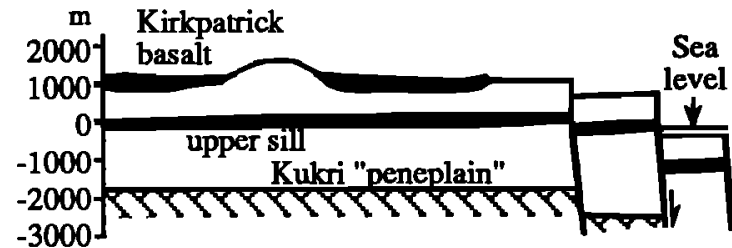

(b)

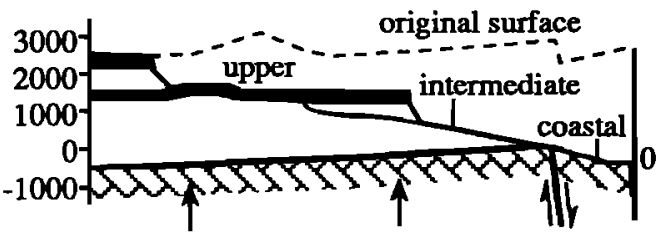

(c)

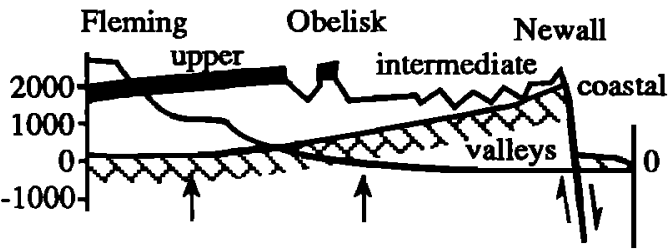

(d)

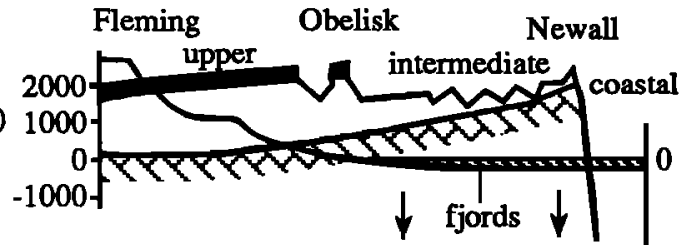

(e)

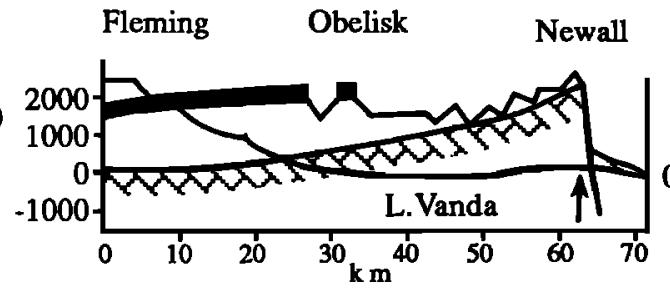

रूरद Kukri 'peneplain'

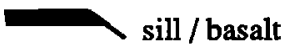

fjords
$\mathbf{E}$

$\begin{array}{lcc}\text { Tectonics } & \begin{array}{l}\text { Denudation } \\ \text { process }\end{array} & \begin{array}{r}\text { Age } \\ \text { (Ma) }\end{array} \\ \text { extension } & & \\ \text { and new } & ? & ? \\ \text { base level } & & \end{array}$

rock uplift, semi-arid faulting? planation

$$
\begin{array}{ll}
\text { rock } & \text { fiords, } \\
\text { subsidence } & \begin{array}{l}
\text { polar desert, } \\
\text { cold-based } \\
\text { glaciers }
\end{array}
\end{array}
$$

$\begin{array}{ll}\text { renewed } & \text { polar desert, }<3.5-0 \\ \text { uplift } & \begin{array}{l}\text { no rivers, } \\ \text { cold-based } \\ \text { glaciers }\end{array}\end{array}$

Figure 10. Empirical model of landscape evolution in the Dry Valleys area of the Transantarctic Mountains showing the situation (a) after initial extension, (b) during planation with a lower base level, (c) after valley downcutting, (d) during a subsequent phase of subsidence, and (e) following further uplift of $300 \mathrm{~m}$ at the mountain front. The possible ages of the stages of evolution, the associated climate, and tectonic environments are also shown.

cause the main valleys to become inundated by the sea, even in sinuous valley sections devoid of significant glacial overdeepening, such as inner Taylor Valley (Figure 10d). In Wright Valley, moraine morphology suggests that the inundation was $300 \mathrm{~m}$ higher than sea level at present [Hall et al., 1993]. If one allows for the marine sediment infill in fluvial parts of Taylor Valley, then the subsidence amounted to $>400 \mathrm{~m}$.
Subsequently, there was a phase of renewed uplift along the mountain front (Figure 10e). This was sufficient to drain the fjords and to create reverse slopes in both Wright and Taylor Valleys. Continuity of slopes across mountain front faults suggests that this recent uplift has not reactivated any faults.

The age of the various stages of landscape evolution is constrained on the one hand by apatite fission track evidence that 
rapid denudation began 55 m.y. ago [Fitzgerald, 1992; Gleadow and Fitzgerald, 1987]. This implies that the planation surfaces and valleys formed after this date. On the other hand, denudation was largely complete by $15 \mathrm{Ma}$, as indicated by the age of the surficial deposits on valley-side slopes (Figure 10c). The timing of the subsidence of the Dry Valleys block to an interval between $>9$ and $<3.5$ m.y. ago is constrained by the age of marine sediments in the mouths of Wright, Taylor, and Ferrar Valleys (Figure 10d).

The ages attributed to the stages of landscape evolution in the model raise one major difficulty, namely, the Sirius Group deposits thought to have been emplaced less than 2-3 m.y. ago by the main ice sheet. If so, then their preservation only on the oldest relict elements of the landscape implies that the planation and valley incision has occurred subsequently. However, the presence of older deposits on these lower dissected slopes and valleys presents a difficulty; it implies that there has been no significant landscape modification in the last $15 \mathrm{~m} . y$. So it is necessary to find an altemative explanation for the age and location of the Sirius Group deposits. At present we have no satisfactory explanation, but it is useful to highlight two further arguments suggesting that the Sirius Group deposits in the Dry Valleys cannot be Pliocene in age. First, we have shown elsewhere that it is possible to fix the limit of those East Antarctic ice sheet outlet glaciers flowing into Taylor Valley during the Pliocene [Denton et al., 1993; Marchant et al., 1994]. Wellconstrained reconstructed profiles based on these limits do not permit ice to be sufficiently thick to cover the adjacent Sirius Group deposit on Mount Feather. Thus it is difficult to envisage the glaciological conditions that could explain this particular Sirius Group deposit. Second, the lack of weathering in Miocene volcanic ashes, their association with cold polar soil wedges, and their preservation in sensitive locations point to continued cold desert conditions since the mid-Miocene [Marchant et al., 1993c]. This would seem to preclude the possibility of the mild conditions necessary to explain the remains of temperate vegetation in the Sirius Group deposits.

The climatic environment associated with landscape evolution in our model is based on the dominant landform associations. We have argued that planation and at least the initial valley cutting probably occurred in semiarid conditions with scanty regolith and vegetation and yet sufficient flash floods to favor pediplanation [Denton et al., 1993]. Although downcutting may have been wholly related to base level changes as a result of uplift, it is possible that it could be partially caused by the onset of wetter conditions. In such a case thicker, regolith would produce convex-concave slopes and favor incision of river valleys, aided perhaps by intermittent glaciation. A more humid climate during the early Oligocene to early Miocene is consistent with the results of the nearby CIROS-1 drill hole which found leaves of Nothofagus of Oligocene age [Barrett et al., 1989]. The cold polar desert conditions of the last 15 m.y. associated with little sign of running water help to explain the preservation and association of volcanic ashes with cold climate landforms [Marchant et al., 1993b]. The lack of water would also explain why the main rivers were unable to excavate their valleys in spite of modest rates of surface uplift in the last 15 m.y. It would also explain the minimum thickness of late Miocene and Pliocene sediments in the CIROS-1 drill hole immediately offshore [Barrett et al., 1989].

\section{Wider Implications}

Although the model of landscape evolution is tentative and incomplete, it has the merit of integrating the sequence of landscape evolution with tectonic evidence and producing a combined interpretation which is consistent. There are several important implications for our understanding of the evolution of passive continental margins.

The landform evidence suggests that since continental separation, denudation has removed a wedge of rock over $4 \mathrm{~km}$ thick at the coast and $1 \mathrm{~km}$ thick $75 \mathrm{~km}$ inland. At the same time, assuming an initial elevation of $1200 \mathrm{~m}$, the land surface elevation has been lowered by $1 \mathrm{~km}$ in the downfaulted coastal zone and has been raised by $0.8 \mathrm{~km}$ on the rift shoulder of the mountain front and by $1 \mathrm{~km}$ at the head of the valleys $75 \mathrm{~km}$ inland. If the initial elevation is correct, then crustal uplift since rifting has been at least $3 \mathrm{~km}$ at the downfaulted coast, $4 \mathrm{~km}$ at the mountain front, and $2 \mathrm{~km} 75 \mathrm{~km}$ inland. These latter figures agree with the view that uplift has been greatest on the rift shoulder and has declined progressively inland [Gleadow and Fitzgerald, 1987; Fitzgerald, 1992; Ten Brink and Stern, 1992]. The smaller magnitude of our figures is the result of the difference in assumed initial elevation.

Our reconstruction of landscape evolution places some constraints on the tectonic processes involved. Rates of denudation were high in the early Cenozoic and tailed off to virtually nothing by $15 \mathrm{Ma}$. The change from high to low rates of denudation during the Cenozoic is most simply explained by a progressively decreasing fall in base level following an initial change. The initial rift allowed planation to extend inland from the new coast. Subsequent valley downcutting (and some planation?) was associated with crustal uplift and faulting at the mountain front. Uplift later gave way to subsidence, as reflected by the incursion of the Miocene/Pliocene sea into the lower valleys to levels $300 \mathrm{~m}$ above those at present. The survival of ancient river valleys graded close to present sea level in this part of the Transantarctic Mountains suggests that subsequent uplift has been limited. This latter conclusion agrees with Wilch et al., [1993a], who used the presence of volcanic cones in Taylor Valley to suggest that surface uplift can have been no more than $300 \mathrm{~m}$ in the last $2.54 \mathrm{~m} . \mathrm{y}$.

This pattern of denudation and uplift is consistent with the evolution of an upper plate passive mountain range. The initial Cenozoic base level change agrees with the view of Fitzgerald [1992] that the Transantarctic Mountains form the upthrown block of an asymmetric rift. Such asymmetry explains the existence of an uplifted flank which creates a large initial base level change and permits scarp retreat from the new coast. The evidence of crustal uplift soon after rifting, followed by subsidence, points to the role of thermal processes. Typically, thermal uplift by lateral heat conduction or secondary convection would be expected to lead to initial uplift of $500-1500 \mathrm{~m}$ [Summerfield, 1988]. Such uplift could follow rifting after a lag of 10-20 m.y. and decay with time, eventually leading to subsidence [Steckler, 1985; Fleitout et 
al., 1986]. Such a process would explain the crustal uplift associated with faulting in the early Cenozoic and the subsidence of several hundred meters in the Miocene.

Another process likely to have played a role is flexural uplift in response to isostatic unloading. Gilchrist and Summerfield [1990] note how this can be expected to lead to long-term surface uplift, initially at the coast but migrating inland with the progression of the escarpment. Such an effect has been calculated to account for about $600 \mathrm{~m}$ of uplift along part of the western margin of southern Africa. In the Dry Valleys, it could account for a comparable amount of uplift in the early Cenozoic. Yet another process of uplift could be glacio-isostatic and could be related to a forebulge beyond the margin of the East Antarctic ice sheet. Although the amplitude of such an effect is less than about $100 \mathrm{~m}$ [Stern and Ten Brink, 1989], it could have been contributed to some of the uplift since the Miocene.

\section{Conclusion}

This view of modest mountain uplift since the Pliocene and limited geomorphic activity since the mid-Miocene differs from the alternative view of $1-2 \mathrm{~km}$ of uplift since the Pliocene and rather dynamic changes in glaciation and vegetation, as suggested elsewhere [Webb and Harwood, 1987; Webb et al., 1984; McKelvey et al., 1991; Barrett et al., 1992]. The apparent youth of the Sirius group deposits is the one piece of evidence that does not fit our geomorphological reconstruction. We have no accepted explanation for the apparent age of the Sirius Group deposits. We would simply note that our geomorphic reconstruction is underpinned by a considerable number of absolute dates and that it agrees well with all other known geophysical evidence. While we recognize that we have studied only one block of the Transantarctic Mountains, the conclusions reached here may have wider implications.

Acknowledgments. The research was supported by the Division of Polar Programs of the National Science Foundation, the U.K. Natural Environment Research Council, the Royal Society, and the Royal Society of Edinburgh. We are very grateful to Paul Fitzgerald and Michael Summerfield for valuable comments on an early draft, and to four referees whose constructive comments improved the manuscript markedly.

\section{References}

Augustinus, P.C., and M.J. Selby, Rock slope development in McMurdo Oasis, Antarctica, and implications for interpretations of glacial history, Geogr. Annlr. Stockholm, $72 A$ (1), 55-62. 1990.

Ballance, P.F., and W.A. Watters, The Mawson diamictite and the Carapace sandstone. Formations of the Ferrar Group at Allan Hills and Carapace Nunatak, Victoria Land, Antarctica, N. Z. J. Geol. Geophys., 14, 512-527, 1971.

Barrett, P.J., History of the Ross Sea region during the deposition of the Beacon Supergroup $400-180$ million years ago, J. R. Soc. N. Z., 11, 447-458, 1981.

Barrett, P.J., and M.J. Hambrey, Plio-Pleistocene sedimentation in Ferrar Fiord, Antarctica, Sedimentology, 39, 109-123, 1992.

Barrett, P.J., and R.D. Powell, Middle Cenozoic glacial beds at Table Mountain, Southem Victoria Land, in Antarctic Geoscience Symposium on Antarctic Geology and Geophysics, edited by C.
Craddock, pp. 1059-1067, University of Wisconsin Press, Madison, 1982.

Barrett, P.J., M.J. Hambrey, D.M. Harwood, A.R. Pyne and P.N. Webb, Synthesis, in Antarctic Cenozoic History From the CIROS-1 Drillhole, McMurdo Sound, edited by P.J. Barrett, DSIR Bull. N.Z., 245, 241-251, 1989.

Barrett, P.J., C.J. Adams, W.C. McIntosh, C.C. Swisher, and G.S. Wilson, Geochronological evidence supporting Antarctic deglaciation three million years ago, Nature, 359, 816-818, 1992.

Behrendt, J.C. and A. Cooper, Evidence of rapid Cenozoic uplift of the shoulder escarpment of the Cenozoic West Antarctic rift system and a speculation on possible climate forcing, Geology, 19, 315-319, 1991.

Behrendt, J.C., W.E. Lemasurier, A.K. Cooper, F. Tessonsohn, A. Trehu, and D. Damaske, Geophysical studies of the West Antarctic rift system, Tectonics, 10, 1257-1273, 1991.

Brady, H., Late Cenozoic history of Taylor and Wright Valleys and McMurdo Sound inferred from diatoms in Dry Valleys Drilling Project Cores, in Antarctic Geoscience Symposium on Antarctic Geology and Geophysics, edited by C. Craddock, pp. 1123-1131, University of Wisconsin Press, Madison, 1982.

Brady, H., and B. McKelvey. The interpretation of a Tertiary tillite at Mount Feather, southern Victoria Land, Antarctica, J. Glaciol., 29(102), 189-193, 1979.

Brown, R.W., M. A. Summerfield, and A. J. W. Gleadow, Apatite fission track analysis: Its potential for the estimation of denudation rates and implications for models of long-term landscape development, in Process Models and Theoretical Geomorphology, edited by M. J. Kirkby, pp. 23-53, John Wiley, New York, 1994.

Bull, C.B.B., B.C. McKelvey, and P.N. Webb, Quatemary glaciations in Southem Victoria Land, Antarctica, J. Glaciol., 4(31), 63-78, 1962.

Burckle, L.H. A critical review of the micropalaeontological evidence used to infer a major drawdown of the East Anatarctic Ice Sheet during the early Pliocene, in Climate and Evolution, edited by E.S. Vrba, Yale University Press, New Haven, Conn., in press, 1995.

Burckle, L.H., and C.M. Pokras, Implications of a Pliocene stand of Nothofagus (Southem Beech) within 500 kilometres of the South Pole, Antarct. Sci., 3, 389-403, 1991.

Calkin, P.E., Processes in the ice-free valleys of southern Victoria Land, Antarctica, in Research in Polar and Alpine Geomorphology, edited by B.D. Fahey and R.D. Thompson, pp. 167-186, Department of Geography, University of Guelph, Ontario, Canada, 1974a.

Calkin, P.E., Subglacial geomorphology surrounding the ice-free valleys of southem Victoria Land, Antarctica, J. Glaciol., 13(69), 415-429, $1974 \mathrm{~b}$.

Carson, M.A., and M.J. Kirkby, Hillslope Form and Process, 375 pp., Cambridge University Press, New York, 1972.

Cooper, A.K., F.J. Davey, and K. Hinz, Crustal extension and origin of sedimentary basins beneath the Ross Sea and Ross Ice Shelf, Antarctica, in Geological Evolution of Antarctica, edited by M.R.A. Thomson, J.A. Crane. and J.W. Thomson, pp. 285-291, Cambridge University Press, New York, 1991.

Davey, F.J., and D.A. Christoffel, Correlation of seismic reflection data, in Antarctic Cenozoic History From the MSSTS-1 Drillhole, McMurdo Sound, edited by P.J. Barrett, DSIR Bull.N. Z., 237, 405-412, 1986.

David, T.W.E., and R.E. Priestley, Glaciology, physiography, stratigraphy and tectonic geology of South Victoria Land, in British Antarctic Expedition 1907-09, Reports on the Scientific Investigations, Vol. 1, Geology, 319 pp, Heinemann, London, 1914. 
Denton, G.H., R.L. Armstrong, and M. Stuiver, The Late Cenozoic glacial history of Antarctica, in The Late Cenozoic Glacial Ages, edited by K.K. Turekian, Pp. 267-306, Yale University Press, New Haven, Conn.,1971.

Denton, G.H., M.L. Prentice, D.E. Kellogg, and T.B. Kellogg, Late Tertiary history of the Antarctic ice sheet: Evidence from the Dry Valleys, Geology, 12, 263-267, 1984.

Denton, G.H., M.L. Prentice, and L.H. Burckle, Cainozoic history of the Antarctic ice sheet, in The Geology of Antarctica, edited by $R$. Tingey, pp. 365-443, Oxford University Press, New York, 1990.

Denton, G.H., D.E. Sugden, D.R. Marchant, B.L. Hall and T.I. Wilch, East Antarctic Ice Sheet sensitivity to Pliocene climatic change from a Dry Valleys perspective, Geogr. Annlr. Stockholm, 75A(4), 155-204, 1993.

Ferrar, H.T., Report on the field geology of the region explored during the 'Discovery' Antarctic Expedition, 1901-4, National Antarctic Expedition 1901-4, Natural History, vol. 1, Geology, British Museum, London, 1907.

Fisher, R.V. and H.U. Schminke, Pyroclastic Rocks, Springer-Verlag, New York, 1984.

Fitzgerald, P.G., The Transantarctic Mountains of Southem Victoria Land: The application of fission track analysis to a rift shoulder uplift, Tectonics, 11, 634-662, 1992.

Fitzgerald, P.G., M. Sandiford, P.J. Barrett, and A.J.W. Gleadow, Asymmetric extension association with uplift and subsidence of the Transantarctic Mountains and Ross Embayment, Earth Planet. Sci. Lett., 81, 67-78, 1986.

Fleitout, L., C. Froidevaux, and D. Yuen, Active lithospheric thinning, Tectonophysics, 132, 271-278, 1986.

Gilchrist, A.R., and M.A. Summerfield, Differential denudation and flexural isostasy in the formation of rifted-margin upwarps, Nature, $346,6286,739-742,1990$.

Gilchrist, A.R., and M.A. Summerfield, Tectonic models of passive margin evolution and their implications for theories of long-tem landscape development, in Process Models and Theoretical Geomorphology, edited by M.J. Kirkby, pp. 55-84, John Wiley, New York, 1994.

Gleadow, A.J.W., and P.G. Fitzgerald, Uplift history and structure of the Transantarctic Mountains and new evidence from fission track dating of basement apatites in the Dry Valleys area, Southem Victoria Land, Earth Planet. Sci. Lett., 82, 1-14, 1987.

Gunn, B.M., and G. Warren, Geology of Victoria Land between the Mawson and Mulock Glaciers, Antarctica, Bull.N.Z. Geol. Surv. 71, 157 pp., 1962.

Hall, B.L., G.H. Denton, D.R. Lux and J.G. Bockheim, Late Tertiary Antarctic paleoclimate and ice-sheet dynamics inferred from surficial deposits in Wright Valley, Geogr. Annlr. Stockholm, 75A(4), 239268, 1993.

Hamilton, W., P.J. Hayes, R. Calvert, V.C. Smith, S.D. Elmore, P. R. Bamett, and N. Conklin, Diabase sheets of the Taylor Glacier region, Victoria Land, Antarctica, US. Geol. Surv. Prof. Pap., 456B, 71 pp., 1965.

Harwood, D.M., Siliceous microfossils, in Antarctic Cenozoic History From the CIROS-1 Drillhole, McMurdo Sound, edited by P.J. Barrett, DSIR Bull. N.Z., 245, 67-97, 1989.

Ishman, S.E. and H.J. Rieck, A Late Neogene Antarctic glacio-eustatic record, Victoria Land Basin margin, Antarctica, in The Antarctic Paleoenvironment: A Perspective on Global Change, Part 1, Antarct.
Res. Ser., vol. 56, edited by J. P. Kennett and D. A. Wamke, Pp. 327347, Washington, D. C., 1992.

Lemasurier, W.E., and D.C. Rex, The Marie Byrd Land volcanic province and its relation to the Cainozoic West Antarctic rift system, in The Geology of Antarctica, edited by R. J. Tingey, pp. 249-284, Oxford University Press, New York, 1991.

Lister, G.S., M.A. Etheridge, and P.A. Symonds, Detachment faulting and the evolution of passive continental margins, Geology, 14, 46-250. 1986.

Lister, G.S., M.A. Etheridge, and P.A. Symonds, Detachment models for the formation of passive continental margins, Tectonics, 10, 10381064, 1991.

McGinnis, L.D. (Ed.), Dry Valleys Drilling Project, Antarct. Res. Ser., vol. 33, 765 pp., AGU, Washington, D.C., 1981.

Marchant, D.R., C.C. Swisher III, D.R. Lux, D.P., West, Jr. and G.H. Denton, Pliocene paleoclimate and East Antarctic ice-sheet history from surficial ash deposits, Science, 260, 667-670, 1993a.

Marchant, D.R., G.H. Denton, and C.C. Swisher III, Miocene-PliocenePleistocene glacial history of Arena Valley, Quartermain Mountains, Antarctica, Geogr. Annlr. Stockholm, 75A (4), 269-302, $1993 \mathrm{~b}$.

Marchant, D.R., G.H. Denton, D.E. Sugden, and C.C. Swisher III, Miocene glacial stratigraphy and landscape evolution of the Western Asgard Range, Antarctica, Geogr. Annlr. Stockholm, 75A (4), 303-330, 1993c.

Marchant, D.R., G.H. Denton, J.G. Bockheim, S.C. Wilson, and A.R Kerr, Quatemary changes in level of upper Taylor Glacier, Antarctica: Implications for palaeoclimate and East Antarctic Ice Sheet dynamics, Boreas, 25, 29-43, 1994.

Marchant, D.R., C.C. Swisher III, N. Potter, and G.H. Denton, Antarctic paleoclimate reconstructed from volcanic ashes in the Dry Valleys region, sourhem Victoria Land, Geol. Soc. Am. Bull., in press, 1995.

McKelvey, B.C., The Cainozoic glacial record in south Victoria Land: A geological evaluation of the McMurdo Sound drilling projects, in The Geology of Antarctica, edited by R.J. Tingey, pp. 434-449, Oxford University Press, New York, 1991.

McKelvey, B.C., P.N. Webb, D.M. Harwood and M.C.G. Mabin, The Dominion Range Sirius Group: A record of the late Pliocene-early Pleistocene Beardmore Glacier, in Geological Evolution of Antarctica, edited by M.R.A. Thomson, J.A. Crane, and J.W. Thomson, pp. 675-682, Cambridge University Press, New York, 1991.

Mudrey, M.G., and L.D. McGinnis, Dry Valleys Drilling Project, Bull. 5 , North. Ill. Univ., De Kalb, 1975.

Nichols, R.L., Glacial geology of the Wright Valley, McMurdo Sound, in Research in the Antarctic, edited by L.O. Quam, pp. 293-340, American Association for the Advancement of Science, Washington, D. C., 1971.

Prentice, M.L., J.G. Bockheim, S.C. Wilson, L.H. Burckle, D.A. Hodell, C. Schluchter, and D.E. Kellogg, Late Neogene Antarctic glacial history: Evidence from central Wright Valley, in The Antarctic Paleoenvironment: A Perspective on Global Changes, 2, Antarc. Res. Ser., vol. 60, edited by J. P. Kennett and D. A. Wamke, pp. 207-250, AGU, Washington, D C., 1993.

Selby, M.J., Slopes and their development in an ice-free, arid area of Antarctica, Geogr. Annlr. Stockholm, 53A(3-4), 235-245, 1971.

Selby, M.J., Slope evolution in an Antarctic oasis, N.Z. Geogr., 30(1), 18-34, 1974. 
Selby, M.J., Hillslope Materials and Processes, 451 pp., Oxford University Press, New York, 1993.

Selby, M.J., and A.T. Wilson, Possible Tertiary age for some Antarctic cirques, Natwre, 229, 623-24, 1971.

Steckler, M.S., Uplift and extension at the Gulf of Suez; indications of induced mantle convection, Nature, 317, 135-139, 1985.

Stem, T.A., and U.S. Ten Brink, Flexural uplift of the Transantarctic Mountains, J. Geophys. Res., 94, 10315-10330, 1989.

Sugden, D.E., Landscapes of glacial erosion in Greenland and their relationship to ice, topographic and bedrock conditions, in Progress in Geomorphology, edited by R.S. Waters and E.H. Brown, Spec. Publ. Inst. Brit. Geogr., 7, 177-195, 1974.

Sugden, D.E., G.H. Denton and D.R. Marchant, Subglacial meltwater channel systems and ice sheet overriding, Asgard Range, Antarctica, Geogr. Annlr. Stockholm, 73A(2), 109-121, 1991.

Sugden, D.E., D.R. Marchant, N. Potter, R. Souchez, G.H. Denton, C.C. Swisher, III, and J-L. Tison, Miocene glacier ice in Beacon Valley, Antarctica, Nature, 1995.

Summerfield, M.A., Global tectonics and landform development, Prog. Phys. Geogr., 12, 389-404, 1988.

Taylor, G., The Physiography of McMurdo Sound and Granite Harbour Region, British Antarctic (Terra Nova) Expedition, 1910-13, Harrison, London, 1922.

Ten Brink, U., and T. Stem, Rift flank upflifts and hinterland basins: Comparison of the Transantarctic Mountains with the great escarpment of southern Africa, J. Geophys. Res., 97, 569-585, 1992.

Tessensohn, F., and G. Worner, The Ross Sea rift system, in Geological Evolution of Antarctica, edited by M.R.A. Thomson, J.A. Crane, and J.W. Thomson, pp. 273-277. Cambridge University Press, New York, 1991.
Van Der Wateren, F.M., and A.L.L.M. Verbers, Cenozoic glacial geology and mountain uplift in northern Victoria Land, Antarctica, in Recent Progress in Earth Science, edited by Y. Yoshida et al., pp. 707-714, Terra Scientific, Tokyo, 1992.

Verbers, A.L.L.M., and F.M. Van Der Wateren, A glacio-geological reconnaissance of the southem Prince Albert Mountains, Victoria Land, Antarctica, in Recent Progress in Earth Science, edited by Y. Yoshida et al., pp. 715-719. Terra Scientific, Tokyo, 1992.

Webb, P.N., and D.M. Harwood, The Sirius formation of the Beardmore region, Antarct. J. U.S., 22, 8-12. 1987.

Webb, P.N., D.M., Harwood, B.C. McKelvey, J.H. Mercer, and L.D. Stott, Cenozoic marine sedimentation and ice volume variation on the East Antarctic craton, Geology, 12, 287-291, 1984.

Wilch, T.L., D.R. Lux, G.H. Denton, and W.C. McIntosh, Minimal PlioPeistocene surface uplift in the Dry Valleys sector of the Transantarctic Mountains, Geology, 21, 841-44, 1993a.

Wilch, T.L., G.H. Denton, D.R. Lux, and McIntosh, W.C., Limited Pliocene glacier extent and surface uplift in middle Taylor Valley, Antarctica, Geogr. Annir. Stockholm, 75A(4), 331-351, 1993b.

Wright, C.S., and R.E. Priestley, Glaciology, British Antarctic (Terra Nova) Expedition 1910-13, vol. 2, 581 pp., Harrison, London, 1922.

G.H. Denton and D. R. Marchant, Institute for Quaternary Studies, University of Maine, Orono, ME 04469.

D.E. Sugden, Department of Geography, University of Edinburgh, Drummond Street, Edinburgh, EH8 9XP, Scotland. (email: DES@geovax.ed.ac.uk)

(Received November 2, 1993; revised October 26. 1994;

accepted November 2, 1994.) 